\title{
AKUNTANSI KEUANGAN LANJUTAN 1
}

\section{PROGRAM HIBAH PENULISAN BUKU AJAR}

\section{TAHUN 2019}

PENULIS :

SARWENDA BIDURI, SE.,M.SA

(NIDN: 0702048501)

UNIVERSITAS MUHAMMADIYAH SIDOARJO 
PENULIS :

SARWENDA BIDURI, SE.,M.SA

(NIDN: 0702048501)

Diterbitkan oleh

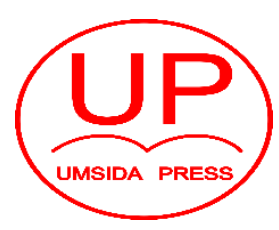

UMSIDA PRESS

Jl. Mojopahit 666 B Sidoarjo 


\section{KATA PENGANTAR}

Alhamdulillah, puji syukur penulis panjatkan kehadirat Alloh SWT, yang telah melimpahkan rahmat dan ridho-Nya sehingga buku "Akuntansi Keuangan Lanjutan 1" dapat penulis selesaikan.

Buku Akuntansi Keuangan Lanjutan 1 ini seluruhnya terdiri dari 10 bab yang terbagi dalam 3 bagian; Bagian I ditujukan untuk memberikan pemahaman tentang gambaran umum akuntansi pendirian firma/persekutuan. Bagian II menguraikan tentang akuntansi untukperubahan pemilikan firma/persekutuan. Bagian III akuntansi pembubaran firma/persekutuan.

Penulis berharap dengan memaparkan berbagai aspek yang berhubungan dengan kegiatan akuntansi keuangan lanjutan 1 dalam 10 bab, buku ini sudah dapat memberikan ilmu kepada para mahasiswa yang mempelajari mata kuliah akuntansi keuangan lanjutan 1 untuk dapat memahami pencatatan keuangan pada suatu perusahaan, khususnya firma/persekutuan

Akhirnya saya berharap semoga buku ini dapat memberikan manfaat kepada sesama manusia dan besar harapan penulis agar pembaca dapat menjadikan buku akuntansi keuangan lanjutan 1 ini sebagai referensi dalam proses pembelajaran.

\section{Penulis}




\section{DAFTAR ISI}

\section{KATA PENGANTAR}

\section{BAB 1}

\section{Kombinasi Bisnis}
A. Pendahuluan
B. Latar Belakang
C. Kombinasi Bisnis dan Pengendalian
D. Akuntansi Kombinasi Bisnis
E. Penyajian dan Pengungkapan Kombinasi Bisnis
F. Analisis Laporan Keuangan

\section{BAB 2}

\section{Akuntansi Untuk Pendirian Firma}
A. Pendahuluan
B. Akuntansi Pendirian Firma/Persekutuan
C. Firma Didirikan Oleh Anggota-Anggota yang Semuanya Belum Memiliki Usaha
D. Firma Didirikan Oleh Anggota-Anggota yang Sudah dan Anggota yang Belum Memiliki Usaha
E. Firma Didirikan Oleh Anggota-Anggota yang Semuanya Sudah Memiliki Usaha

\section{BAB 3}

\section{Pembagian Laba Rugi Firma}
A. Laba Rugi Dibagi Sama
B. Laba Rugi Dibagi Berdasarkan Perbandingan Tertentu yang telah Disepakati
C. Laba Rugi Dibagi Sesuai dengan Perbandingan Modal Awal
D. Laba Rugi Dibagi Sesuai dengan Perbandingan Modal Akhir 
E. Laba Rugi Dibagi Sesuai dengan Perbandingan Modal Rata-Ratal

F. Laba Rugi Dibagi Sama Setelah Dikurangi Gaji dan Bonus

G. Laba Rugi Dibagi Sama Setelah Dikurangi Bunga Modal Rata-Rata

\section{BAB 4}

\section{Akuntansi Untuk Perubahan Pemilikan Persekutuan}
A. Pendahuluan
B. Perubahan Pemilikan Firma Akibat Adanya Anggota Baru yang Masuk
C. Perubahan Pemilikan Firma Akibat Adanya Anggota Baru yang Keluar

\section{BAB 5}

\section{Akuntansi Pembubaran Firma}
A. Pendahuluan
B. Akuntansi pembubaran persekutuan dengan Metode Likuidasi dilakukan secara serentak
C. Pembubaran persekutuan dengan Metode Likuidasi dilakukan secara berangsur

\section{BAB 6}

\section{Akuntansi Untuk Penjualan Angsuran Aktiva Tetap}

A. Pendahuluan

B. Penjualan Angsuran Aktiva Tetap

C. Penjualan Angsuran Aktiva Tetap Dengan Menggunakan Metode Laba Diakui Pada saat Penjualan Angsuran Dilakukan

D. Penjualan Angsuran Aktiva Tetap Dengan Menggunakan Metode Laba Diakui Proporsionil Dengan Penerimaan Kas dari Pelunasan Angsuran 
E. Kegagalan Pelunasan Piutang Angsuran Aktiva Tetap

\section{BAB 7}

\section{Akuntansi Untuk Penjualan Angsuran Barang Dagangan}
A. Pengertian Penjualan Angsuran Barang Dagangan
B. Masalah Pemilikan Kembali Barang Dagangan
C. Masalah Tukar Tambah (Trade-In) Dalam Penjualan Angsuran

\section{BAB 8}

Akuntansi Penjualan Konsinyasi Untuk Pengamanat (Consignor)
A. Pendahuluan
B. Akuntansi Konsinyasi Pengamanat Dengan Menggunakan Metode Laba Terpisah
C. Akuntansi Konsinyasi Untuk Pengamanat Dengan
Menggunakan Metode Laba Tak Terpisah

\section{BAB 9}

Akuntansi Penjualan Konsinyasi Untuk Komisioner (Consignee)
A. Pendahuluan
B. Akuntansi Konsinyasi Untuk Komisioner Dengan Menggunakan Metode Laba Terpisah
C. Masalah Uang Muka Dalam Penjualan Konsinyasi
D. Akuntansi Konsinyasi Untuk Komisioner Dengan

\section{BAB 10}

Masalah Barang Konsinyasi Yang Belum Terjual Sampai Akhir Periode Akuntansi
A. Pendahuluan
B. Barang Konsinyasi Yang Belum Terjual Pada Akhir Periode Untuk Pengamanat


C. Barang Konsinyasi Yang Belum Terjual Pada Akhir Periode Untuk Komisioner

\section{BATANG TUBUH}

BAB 1

Kombinasi Bisnis

\section{Capaian Pembelajaran (CP):}

a. Mahasiswa dapat menjelaskan tujuan dan motivasi kombinasi bisnis

b. Mahasiswa dapat menjelaskan konsep pengendalian dan kombinasi bisnis

c. Mahasiswa dapat menerapkan pencatatan dan pengukuran transaksi kombinasi bisnis

d. Mahasiswa dapat menerapkan penyajian dan pengungkapan kombinasi bisnis

\section{A. Kombinasi Bisnis dan Pengendalian}

Berdasarkan pernyataan standar akuntansi keuangan (PSAK) No. 22 tahun 2015 "Penggabungan usaha (business combination) adalah pernyataan dua atau lebih perusahaan yang terpisah menjadi satu entitas ekonomi karena satu perusahaan menyatu dengan (uniting wiith) perusahaan lain atau memperoleh kendali (control) atas aktiva dan operasi perusahaan lain". Pengendalian yang dimaksud adalah kekuasaan untuk mengatur kebijakan keuangan dan operasi suatu entitas demi memperoleh manfaat dari aktivitas entitas tersebut.Entitas adalah badan yang terpisah dari pemiliknya. Kombinasi bisnis melibatkan 2 pihak yaitu entitas pengakuisisi dan entitas yang diakuisisi. 
Entitas pengakuisisi adalah entitas yang memperoleh pengendalian atas entitas yang di akuisisi dalam transaksi kombinasi bisnis; sedangkan entitas yang diakuisisi atau entitas target merupakan entitas dalam transaksi kombinasi bisnis dikendalikan oleh entitas lain.

Berdasarkan GAAP terbaru, pengendalian sederhananya terjadi ketika sebuah perusahaan memiliki mayoritas kepentingan ekuitas pada perusahaan lain.

\section{B. Akuntansi Kombinasi Bisnis}

Kombinasi bisnis pada umumnya terjadi dengan kepemilikan hak suara yang memberikan hak pengendalian. Kepemilikan hak suara biasanya direalisasi dengan perolehan ekuitas entitas lain, sebagai contoh, hak suaradalam entitas yang berbentuk peseroan terbatas dinyatakan dalamkepemilikan saham biasa PSAK 22 revisi tahun 20102 mensyaratkan penerapan metode pembelian (purchase) atau metode akuasisi untuk perolehan ekuitas entitas yang dimaksud. Pembahasan selanjutnya mengasumsikan bahwa kombinasi bisnis terjadi diantara entitas yang berbentuk peseroan terbatas melalui akuisisi saham biasa kecuali disebut khusus.

Secara umum, tujuan dari kombinasi bisnis adalah meningkatkan profitabilitas dan efisiensi. Secara khusus, kombinasi bisnis dilakukan untuk :

a. Penghematan biaya

Dengan kombinasi bisnis, berbagai biaya bisa dihemat. Diantaranya biaya gaji berbagai manajer, biaya penelitian produk baru (produk tersebut sudah ada di perusahaan yang diakuisisi) dan biaya penelitian dan pengembangan.

b. Mengurangi risiko

Membeli perusahaan yang sudah mempunyai berbagai macam produk, dan juga pasarnya, akan lebih kecil 
resikonya dibandingkan dengan mengembangkan dan memasarkan produk baru.

c. Mengurangi penundaan beroperasinya perusahaan

Membeli perusahaan yang sudah mempunyai berbagai macam fasilitas dan sudah memenuhi berbagai macam aturan pemerintah, akan lebih cepat dibandingkan dengan mengembangkan sendiri atau mendirikan perusahaan baru.

d. Menghindari pengambilalihan oleh perusahaan lainnya Salah satu cara untuk menghindari pengambilalihan oleh perusahaan lain adalah dengan melakukan kombinasi bisnis.

e. Memperoleh aset tidak berwujud

Salah satu alasan untuk melakukan kombinasi bisnis adalah untuk memperoleh aset tidak berwujud yang dimiliki oleh perusahaan yang diakuisisi seperti hak paten, hak penambangan, database pelanggan dan lain-lain.

f. Alasan-alasan lain

Ada perusahaan yang punya kebanggaan tersendiri ketika berhasil mengakuisisi perusahaan-perusahaan lain.

\section{METODE AKUNTANSI KOMBINASI BISNIS}

a. Penyatuan kepemilikan (uniting of interest/pooling of interest)

Suatu penggabungan usaha dimana para pemegang saham perusahaan yang bergabung bersama-sama menyatukan kendali atas seluruh, atau secara efektif seluruh aktiva neto dan operasi kendali perusahaan yang bergabung tersebut dan selanjutnya memikul bersama segala resiko dan manfaat yang melekat pada entitas gabungan, sehingga tidak ada pihak yang dapat diidentifikasi sebagai perusahaan pengakuisisi (acquirer). 
Terdapat dua metode untuk memperoleh kepemilikan mayoritas pada perusahaan lain:

(1). Perusahaan pengakuisis membeli saham ber-hak suara dari perusahaan terakuisis dengan tunai

(2). perusahaan pengakuisisi menukar saham ber-hak suara-nya dengan saham ber-hak suara dari perusahaan terakuisisi.

Adapun persyaratannya adalah :

1. $90 \%$ saham harus dimiliki oleh perusahaan yang mengakuisisi

2. Semua pemegang saham harus diperlakukan sama.

Metode ini mengakuisisi dengan menggunakan nilai buku. Hasilnya adalah memiliki pendapatan yang lebih besar karena :

- $\quad$ Depresiasi dan penyusutan lebih rendah dari biaya aset

- $\quad$ Tidak menyebabkan penyusutan goodwill

Metode kombinasi bisnis saat penerbitan FASB Statement No. 141 tahun 2001 adalah Purchase Method ( Metode Pembelian ). Meskipun metode penyatuan kepemilikan sudah tidak digunakan namun perusahaan yang dulunya melakukan kombinasi bisnis dengan metode ini tidak dirubah. Jadi laporan keuangan saat ini pun masih termasuk aktiva dan kewajiban dari perusahaan yang di akuisisi dalam pooling yang awalnya dicatat sebesar nilai buku pada tanggal akuisisi.

b. Purchase Method (Metode Pembelian )

Metode Pembelian yang di persyaratkan dalam FASB Statement No. 141 hanya berfokus pada pencatatan nilai wajar untuk bagian dari aset dan kewajban yang 
diperoleh dalam pembelian. Akun - akun perusahaan yanag diakuisis hanya akan disesuaikan dengan nilai wajar penuh jika perusahaan induk yang memiliki $100 \%$ kepemilikan saham dalam perusahaan yang diauisisi. Tetapi, jika perusahaan membeli hanya $80 \%$ kepemilikan saham diperusahaan yang diakuisisi akun akan disesuaikan hanya dengan $80 \%$ dari perbedaan antara buku dan nilaiwajar.

Contoh :

Dalam 80\% pembelian, aset dengan nilai buku sebesar $\$ 6.000$ dan nilai wajar sebesar $\$ 10.000$ akan tercatat sebesar $\$ 9.200$.

Jawab :

= ( Nilai Buku + Jumlah Kepemilikan Saham dikurangi selisih lebih nilai wajar atas nilai buku )

$=(\$ 6.000+80 \%$ (\$4.000)

$=\$ 9.200$

c. Metode yang digunakan dalam FASB ASC 805 tahun 2007

Metode yang digunakan dalam FASB ASC 805 tahun 2007 adalah Metode Akuisisi. Dengan metode ini, Aset dan liabiliti yang dicatat dengan nilai wajar, dikurangi presentase kepemilika dari pembelian perusahaan oleh pengakuisisi ( dengan catatan pembelian kepentingan cukup besar untuk memiliki pengendalian atas perusahaan yang di akuisisi).

Contoh :

Aset akan dicatat dengan nilai wajar $\$ 10.000$ secara penuh meskipun perusahaan yang mengakusisi hanya membeli $80 \%$ kepemilkikan di perusahaan yang memiliki aset. 
Metode akuisisi juga menghilangkan pendiskontoan aset tetap dan aset tidak berwujud yang kurang dari nilai wajar. Hal ini dapat terjadi ketika adaanya pembelian tawar menawar antar perusahaan. Tawar menawar pembelian terjadi ketika harga yang dibayar kurang dari total nilai aset bersih ( semua aset dikurangi liability ).

C. Penyajian dan Pengungkapan Kombinasi Bisnis

Pengungkapan dan penyajian pada laporan keuangan atas kombinasi bisnis yang ada pada kelompok usahanya. Untuk menciptakan laporan keuangan yang baik maka penyajian goodwill dan aset tak berwujud harus dipisahkan agar pengguna laporan keuangan mudah dalam memahami isi dari laporan keuangan tersebut.

D. Analisis Laporan Keuangan

\section{Laporan Keuangan Konsolidasian}

Melaporkan hasil operasi dan kondisi keuangan perusahaan induk dan anak perusahaannya dalam satu perangkat laporan.

\section{Mekanisme Konsolidasi}

Melibatkan dua langkah, yaitu agregasi dan eliminasi:

1. Laporan keuangan konsolidasian menggabungkan asset, liabilitas, pendapatan, dan beban entitas anak dengan pos-pos terkaitnya dalam laporan keuangan entitas induk.

2. Mengeliminasi transaksi antar perusahaan untuk menghindari perhitungan ganda atau pengakuan laba secara prematur.

\section{Penurunan Nilai Goodwill}

Goodwill merupakan salah satu aset tak berwujud yang timbul sebagai akibat dari merger dan akuisisi. Goodwill 
adalah kelebihan harga beli untuk sebuahbperusahaan di atas fair value dari keseluruhan aset bersih yang diperoleh perusahaan penawar. Goodwill yang dicatat dalam proses konsolidasi memiliki umur yang tak terbatas dan karenanya tidak diamortisasi. Namun goodwill ditelaah setiap tahun untuk penurunan nilai (impairment).

\section{Permasalahan dalam Kombinasi Bisnis Pertimbangan Kontijensi}

Dalam beberapa kombinasi usaha, pihak-pihak tidak menyetujui suatu harga. Hal ini disebut dengan pertimbangan kontinjen, di mana disetujui bahwa penambahan uang akan dibayarkan oleh pembeli kepada penjual jika target kinerja masa depannya tercapai oleh perusahaan yang kombinasi.

\section{Alokasi Total Biaya}

Seluruh aset yang dapat diidentifikasi yang diakuisisi dan kewajiban yang ditanggung dalam penggabungan usaha menerima alokasi total biaya, yang umumnya sama dengan nilai wajar masing-masing pada tanggal akuisisi.

\section{Penelitian dan Pengembangan dalam Proses}

Beberapa perusahaan menghapus sebagian besar biaya akuisisi seperti penelitian dan pengembangannya yang dibeli. Selain itu, terdapat kenaikan drastic dalam penghapusan tersebut khususnya pada industry teknologi tinggi.

\section{Utang Dalam Laporan Keuangan Konsolidasian}

Liabilitas dalam laporan keuangan konsolidasi tidak beroperasi sebagai lawan aset. Dalam hal gagal bayar, kreditor yang dijamin atau tidak dijamin hanya dapat mengklaim aset yang dimiliki oleh perusahaan yang berutang. 


\section{Keuntungan atas IPO Entitas Anak}

a. Kemudahan meningkatkan modal di masa mendatang

b. Meningkatkan likuiditas bagi pemegang saham

c. Nilai pasar perusahaan diketahui.

\section{Penjualan Dan Laba Sebelum Akuisisi}

Saat akuisisi dilakukan di pertengahan tahun, perusahaan hanya melaporkan ekuitas mereka dalam pendapatan dari anak perusahaan dari tanggal akuisisi kedepan. Terdapat dua metode menurut GAAP untuk mencapai hal tersebut:

1. Perusahaan dapat menerbitkan laporan laba rugi konsolidasi dengan penjualan, beban, dan laba anak perusahaan dari tanggal akuisisi ke depan.

2. Perusahaan dapat melaporkan dalam laporan laba rugi konsolidasinya penjualan dan beban anak perusahaan seluruh tahun dan menarik laba sebelum akusisi sehingga hanya laba setelah akuisisi yang dimasukkan dalam laba bersih konsolidasi.

\section{Akuntansi Push And Down}

Sebagai basis akuntansi dan pelaporan baru untuk setiap entitas dengan laporan keuangannya yang terpisah, yang berdasarkan pada transaksi pembelian saham berhak suara, dan yang menghasilkan perubahan kepemilikan saham berhak suara yang beredar. Ketika akuntansi push-down tidak digunakan dalam akuisisi, alokasi harga pembelian pada aktiva bersih berwujud dan goodwill diselesaikan dalam kertas kerja konsolidasi.

\section{Keterbatasan Tambahan Dalam Laporan Keuangan Konsolidasian}


1. Laporan keuangan masing-masing perusahaan yang membentuk entitas yang lebih besar tidak selalu dibuat berdasarkan basis yang dapat diperbandingkan.

2. Laporan keuangan konsolidasi tidak mengungkapkan pembatasan penngunaan kas di masing-masing perusahaan.

3. Perusahaan dengan kondisi keuangan yang buruk sering kali digabungkan dengan perusahaan yang kondisi keuangannya kuat, sehinggamengaburkan analisis kita

4. Tingkat transaksi antarperusahaan tidak dapat diketahui

5. Akuntansi untuk konsolidasi anak perusahaan keuangan dan asuransi menimbulkan masalah khusus bagi analisis. 


\section{BAB 2}

\section{Akuntansi Untuk Pendirian Firma}

\section{Capaian Pembelajaran (CP):}

a. Mahasiswa dapat memahami definisi Firma beserta karakteristiknya

b. Mahasiswa dapat memahami beberapa alternatif cara pendirian Firma

c. Mahasiswa dapat memahami prosedur akuntansi pendirian firma dengan metode pembukuan menggunakan buku baru dan atau metode pembukuan melanjutkan buku milik salah seorang anggota yang sebelumnya sudah mempunyai usaha

\section{A. Akuntansi Pendirian Firma/Persekutuan}

Firma adalah merupakan bentuk perusahaan yang didirikan oleh dua orang atau lebih untuk memperluas usahanya atau untuk memperoleh laba.

Tujuan pendirian firma ini biasanya adalah untuk memperluas usaha \& menambah modal agar lebih kuat \& mampu bersaing dengan perusahaan-perusahaan yang lain. Firma biasanya disebut juga Persekutuan (Partnership), dengan demikian pemilik Firma disebut dengan anggota atau sekutu atau partner. Di dalam firma semua anggota atau sekutu adalah pemilik yang sekaligus merangkap pengelola (manajemen) yang secara langsung aktif melaksanakan usaha perusahaan.

Adapun beberapa karakteristik firma adalah sbagai berikut:

1. Mutual Agency (saling mewakili) 
2. Limited Life (umur terbatas)

3. Unlimited Liability ( tanggungjawab terhadap kewajiban firma tidak terbatas)

4. Ownership of an Interest in a Partnership

5. Perticipating in Partnership Profit

Beberapa perbedaan penting antara firma \& perseroan

\begin{tabular}{|l|l|l|}
\hline Keterangan & Firma & Perseroan \\
\hline $\begin{array}{l}\text { 1. Kesinambungan } \\
\text { usaha }\end{array}$ & $\begin{array}{l}\text { Umur firma terbatas \& } \\
\text { secara hukum } \\
\text { dinyatakan bubar jika } \\
\text { ada perubahan dalam } \\
\text { komposisi sekutu atau } \\
\text { anggota, tetapi secara } \\
\text { ekonomis dapat terus } \\
\text { beroperasi untuk } \\
\text { melanjutkan } \\
\text { usahanya, tidak perlu } \\
\text { dilikuidasi }\end{array}$ & $\begin{array}{l}\text { Umur dianggap tidak } \\
\text { terbatas. Perubahan } \\
\text { mengakibatkan tidak } \\
\text { berakhirnya umur } \\
\text { perseroan. }\end{array}$ \\
\hline 2. Perijinan pendirian & $\begin{array}{l}\text { Diperlukan sedikit } \\
\text { prosedur untuk } \\
\text { memperoleh } \\
\text { formalitas usahanya }\end{array}$ & $\begin{array}{l}\text { Didirikan berdarsarkan ijin } \\
\text { negara \& harus taat pada } \\
\text { aturan-aturan yang telah } \\
\text { ditetapkan. Prosedur untuk } \\
\text { memperoleh ijin usaha } \\
\text { biasanya relatif lama \& } \\
\text { sulit }\end{array}$ \\
\hline
\end{tabular}




\begin{tabular}{|l|l|l|}
\hline $\begin{array}{l}\text { 3. Tanggungjawab } \\
\text { pemilik terhadap } \\
\text { hutang kewajiban }\end{array}$ & $\begin{array}{l}\text { Tanggungjawab setiap } \\
\text { anggota pemilik tidak } \\
\text { terbatas, bahkan } \\
\text { sampai harta milik } \\
\text { pribadinya dijaminkan }\end{array}$ & $\begin{array}{l}\text { Kewajiban pemilik ( } \\
\text { pemegang saham) hanya } \\
\text { terbatas sebesar modal } \\
\text { yang } \\
\text { ditanamkan/diinvestasikan }\end{array}$ \\
\hline $\begin{array}{l}\text { 4. Keterlibatan dalam } \\
\text { pengelolaan } \\
\text { perusahaan }\end{array}$ & $\begin{array}{l}\text { Masing-masing } \\
\text { anggota terlibat aktif } \\
\text { dalam pengelolaan } \\
\text { firma secara langsung }\end{array}$ & $\begin{array}{l}\text { Pemegang saham bisa } \\
\text { tidak aktif dalam } \\
\text { pengelolaan perseroan. } \\
\text { Mereka memilih dewan } \\
\text { Direksi untuk } \\
\text { melaksanakan pengelolaan } \\
\text { langsung terhadap } \\
\text { perseroan }\end{array}$ \\
& & \\
\hline
\end{tabular}

Firma merupakan salah satu unit usaha yang berdiri sendiri \& mempunyai kedudukan yang terpisah dari pemiliknya (business entity.)

Dalam pendirian suatu firma, sebelum operasi biasanya para anggota membuat suatu kesepakatan atau perjanjian yang tertuang dalam akta pendirian yang biasanya berisi tentang hal-hal berikut:

1. Nama \& alamat firma

2. Jenis usaha firma, misalnya usahanya dalam bidang jasa, perdagangan, atau manufaktur

3. Hak \& kewajiban masing-masing anggota, misalnya siapa yang menjadi manajer serta tugas \& wewenang anggota yang lainnya

4. Jumlah modal yang ditanamkan pertama kali oleh masing-masing anggota, termasuk uraian lengkap tentang aktiva non kas yang diserahkan (bila ada) yang digunakan dalam operasi firma

5. Pembagian laba rugi yang biasanya ditunjukkan dalam bentuk rasio antara anggota yang satu dengan yang lainnya 
6. Syarat-syarat pengambilan modal (prive) \& penambahan modal

7. Prosedur penerimaan anggota baru firma

8. Prosedur keluarnya anggota firma

9. Prosedur pembubaran firma apabila firma dilikuidasi

10. Dan uraian penting lainnya

\section{B. Firma Didirikan Oleh Anggota-Anggota yang Semuanya Belum Memiliki Usaha}

Apabila firma didirikan oleh anggota-anggota yang semuanya belum memiliki usaha, maka setoran pertama dari masing-masing anggota tersebut akan langsung di catat dalam rekening modal masing-masing anggota. Apabila ada anggota yang menyetorkan modal pertama berupa aktiva non-kas, maka aktiva non-kas tersebut terlebih dahulu harus dinilai sebesar nilai wajarnya atau harga pasarnya. Jika tidak dapat ditentukan nilai wajar atau harga pasar aktiva non-kas tersebut, maka aktiva tersebut dinilai berdasarkan perjanjian dari anggota.

Contoh 1 :

Pada tanggal 1 Januari 20XY, Tuan Ali, Ahmad, \& Ardi sepakat untuk mendirikan sebuah firma. Berikut ini adalah setoran modal masing-masing anggota :

\begin{tabular}{|c|c|c|c|}
\hline & Tuan Ali & $\underline{\text { Tuan }}$ & $\underline{\text { Tuan Ardi }}$ \\
\hline Kas & Rp 20.000.000 & Ahmad & 5.000 .000 \\
\hline Persediaan & - & - & 8.000 .000 \\
\hline Kendaraan & 3.000 .000 & 16.000 .000 & 7.000 .000 \\
\hline Tanah & - & 0 & 10.000 .000 \\
\hline Bangunan & 2.000 .000 & - & - \\
\hline $\begin{array}{l}\text { Kantor } \\
\text { Jumlah }\end{array}$ & $\operatorname{Rp} 25.000 .000$ & $\begin{array}{l}4.000 .000 \\
-\end{array}$ & 30.000 .000 \\
\hline
\end{tabular}




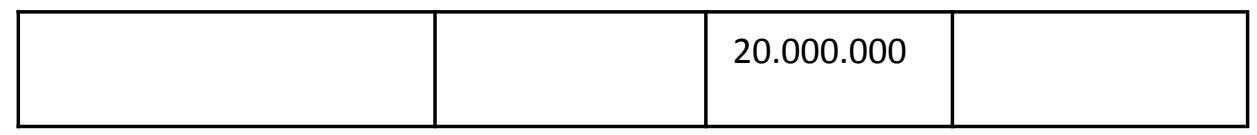

Jurnal yang harus dibuat untuk mencatat transaksi penyetoran modal masing-masing anggota adalah sbb:

1) Kas

Kendaraan

Bangunan Kantor

Modal Tuan Ali
Rp 20.000.000

3.000 .000

2.000 .000

Rp 25.000.000

(Untuk mencatat penyetoran modal Tuan Ali)

2) Persediaan

Rp 16.000.000

Tanah

\subsubsection{0}

Modal Tuan Ahmad

$\mathrm{Rp} 20.000 .000$

(Untuk mencatat penyetoran modal Tuan Ahmad)

3) Kas

Rp 5.000 .000

Persediaan

8.000 .000

Tanah

10.000 .000

Kendaraan

7.000 .000

Modal Tuan Ardi

Rp 30.000.000

(Untuk mencatat penyetoran modal Tuan Ardi)

Setelah jurnal penyetoran modal masing-masing anggota dibuat, maka selanjutnya transaksi penyetoran tersebut diposting ke dalam masing-masing rekening buku besar sehingga pada saat pendirian, firma tersebut memiliki 8 buah buku besar yaitu:

1. Buku besar kas

2. Buku besar persediaan

3. Buku besar tanah

4. Buku besar kendaraan

5. Buku besar bangunan kantor

6. Buku besar modal Tuan Ali

7. Buku besar modal Tuan Ahmad 
8. Buku besar modal Tuan Ardi

Apabila masing-masing rekening sudah dicatat dalam buku besarnya, maka neraca awal pada saat pendirian firma akan tampak sbb:

Firma "AAA"

NERACA AWAL

1 Januari 20XY

\begin{tabular}{|c|c|c|c|c|c|}
\hline \multicolumn{3}{|c|}{ Aktiva Lancar : } & \multicolumn{3}{|c|}{ Hutang : } \\
\hline Kas & $\mathrm{Rp}$ & 25.000 .000 & \multirow{5}{*}{$\begin{array}{l}\text { Modal : } \\
\text { Modal Tn. Ali } \\
\text { Modal Tn. Ahmad } \\
\text { Modal Tn. Ardi } \\
\text { Total Modal }\end{array}$} & \multirow[b]{2}{*}{$\mathrm{Rp}$} & \multirow[b]{2}{*}{25.000 .000} \\
\hline Persediaan Barang & & 24.000 .000 & & & \\
\hline Total Aktiva Lancar & $\mathrm{Rp}$ & 49.000 .000 & & & 20.000 .000 \\
\hline \multicolumn{3}{|c|}{ Aktiva Tetap : } & & & 30.000 .000 \\
\hline Tanah & $\mathrm{Rp}$ & 14.000 .000 & & $\mathrm{Rp}$ & 75.000 .000 \\
\hline Bangunan & & 2.000 .000 & Jumlah Hutang \& Modal & $\mathrm{Rp}$ & 75.000 .000 \\
\hline Kendaraan & & 10.000 .000 & & & \\
\hline Total Aktiva Tetap & $\mathrm{Rp}$ & 26.000 .000 & & & \\
\hline Jumlah Aktiva & $\mathrm{Rp}$ & 75.000 .000 & & & \\
\hline
\end{tabular}

\section{Firma Didirikan Oleh Anggota-Anggota yang Sudah dan} Anggota yang Belum Memiliki Usaha

Apabila firma didirikan oleh salah seorang anggota yang sudah memiliki usaha/ perusahaan perseorangan \& beberapa anggota yang belum memiliki usaha, maka prosedur akuntansinya adalah sbb:

1. Mengadakan penilaian kembali aktiva/ kekayaan milik anggota yang sudah memiliki usaha

2. Mencatat penyetoran kekayaan anggota yang belum memiliki usaha

3. Meyusun neraca awal firma 
Akibat adanya anggota pendiri firma yang sudah memiliki usaha \& yang belum memiliki usaha, maka ada 2 metode akuntansi yang dapat digunakan untuk mencatat pendirian firma, yaitu:

1. Pembukuan firma menggunakan buku-buku baru

2. Pembukuan firma melanjutkan buku milik anggota yang sudah memiliki usaha.

\section{Contoh 2:}

Pada tanggal 3 Maret 20XY, Tuan Arpra, Nyonya Fina, Tuan Riski, \& Nona Rahma bersepakat untuk mendirikan sebuah firma yang bergerak dalam bidang perdagangan konveksi. Nyonya Fina, Tuan Riski \& Nona Rahma adalah merupakan anggota-anggota yang sebelumnya belum memiliki usaha, sedangkan Tuan Arpra sudah memiliki perusahaan perseorangan yang berupa Toko Konveksi pakaian jadiyang pada saat firma akan didirikan mempunyai posisi keuangan sbb:

NERAC A TUAN ARPRA

3 Maret 20XY

\begin{tabular}{|lr|lr|}
\hline Kas & $\mathrm{Rp} 6.000 .000$ & Hutang Dagang & $\mathrm{Rp} 3.500 .000$ \\
Piutang Dagang & 1.500 .000 & Hutang Bank & 4.500 .000 \\
Persediaan Barang & 8.750 .000 & Modal & $\mathrm{Rp} 10.500 .000$ \\
Alat-alat Toko & 2.250 .000 & Total & $\mathrm{Rp} 18.500 .000$ \\
Total & $\mathrm{Rp} 18.500 .000$ & & \\
\hline
\end{tabular}


Sedangkan anggota-anggota yang lainnya menyetorkan kekayaan sbb:

\begin{tabular}{|c|c|c|c|c|c|}
\hline & \multicolumn{2}{|c|}{ Nyonva Fina } & Tuan Riski & Nor & a Rahma \\
\hline Kas & & 12.000 .000 & - & $\mathrm{Rp}$ & 4.600 .000 \\
\hline Persediaan & & - & 16.000 .000 & - & \\
\hline Kendaraan & & 18.000 .000 & - & - & \\
\hline Tanah & & - & - & & 6.000 .000 \\
\hline Peralatan Kantor & & - & 8.000 .000 & - & \\
\hline Bangunan Kantor & & - & - & & 6.000 .000 \\
\hline Jumlah & $\mathrm{Rp}$ & 30.000 .000 & Rp 24.000.000 & $\mathrm{Rp}$ & 16.600 .000 \\
\hline
\end{tabular}

Setelah ke-4 anggota pendiri firma tersebut bersepakat untuk mendirikan firma, maka mereka mengadakan perjanjian mengenai hal-hal berikut:

1. Kas milik Tuan Arpra diambil seluruhnya oleh Tuan Arpra.

2. Persediaan barang dagangan Tuan Arpra dinilai kembali \& diturunkan nilainya sebesar Rp 2.500.000.

3. Hutang bank Tuan Arpra akan dilunasi sendiri oleh Tuan Arpra

4. Tanah milik Nona Rahma diniali kembali sebesar nilai wajarnya, yaitu sebesar Rp 8.400.000

5. Kendaraan milik Nyonya Fina juga dinilai kembali menjadi Rp 18.000 .000

6. Firma tersebut akan diberi nama "KURNIA".

Berdasarkan transaksi pada contoh 2 di atas, maka prosedur akuntansi pendirian firma dengan menggunakan 2 metode pembukuan adalah sbb:

a. Bila Pembukuan menggunakan buku baru 
Jika firma Kurnia menggunakan buku baru, maka prosedur akuntansi yang dilakukan adalah sbb:

1) Mengadakan penyesuaian kekayaan anggota yang sudah memiliki usaha (dalam hal ini Tuan Arpra), yaitu dengan membuat jurnal penyesuaian sesuai dengan perjanjian sbb:

Hutang Bank

Modal Tuan Arpra

Kas

Persediaan
Rp 4.500.000

4.000 .000
Rp 6.000.000

2.500 .000

Akibat adanya jurnal diatas, maka kekayaan \& modal Tuan Arpra akan menjadi sbb:

- Piutang dagang

Rp 1.500.000

- Persediaan barang dagangan :

Rp 8.750.000 - 2.500.000

6.250 .000

- Alat-alat toko

2.250 .000

- Hutang dagang

3.500 .000

- Modal Tuan Arpra :

Rp 10.500.000-4.000.000

6.500 .000

Melakukan penutupan buku rekening-rekening milik Tuan Arpra yaitu dengan membuat jurnal penutup sbb:

Hutang dagang

Rp 3.500.000

Modal Tuan Arpra

6.500 .000

Piutang dagang

Rp 1.500.000

Persediaan

6.250 .000

Alat-alat toko

2.250 .000

Mencatat penyetoran kekayaan anggota-anggota yang belum memiliki usaha, termasuk penyetoran kekayaan Tuan Arpra.

a. Jurnal penyetoran kekayaan Nyonya Fina Kas

Rp 12.000.000 
Modal Nyonya Fina Rp 30.000.000

b. Jurnal penyetoran kekayaan Tuan Riski

$\begin{array}{lr}\text { Persediaan } & \text { Rp } 16.000 .000 \\ \text { Peralatan Kantor } & 8.000 .000\end{array}$

\section{Modal Tuan Riski}

Rp 24.000.000

Jurnal penyetoran kekayaan Nona Rahma

Kas

Tanah

Bangunan
Rp 4.600.000

8.400 .000

6.000 .000

Modal Nona Rahma

Rp 19.000.000

d) Jurnal penyetoran kekayaan Tuan Arpra

Piutang dagang

Persediaan

Alat-alat toko
Rp 1.500.000

6.250 .000

2.250 .000

Hutang dagang

Rp $\quad 3.500 .000$

Modal Tuan Arpra

4) Membuat neraca awal firma Kurnia, yaitu sebesar masing-masing rekening dari transaksi penyetoran kekayaan masing-masing anggota yang sudah dicatat dalam buku besar. Adapun neraca awal adalah sbb:

Firma "KURNIA"

NERACA AWAL 


\begin{tabular}{|c|c|c|c|}
\hline \multicolumn{2}{|l|}{ AKTIVA LANCAR: } & \multicolumn{2}{|l|}{ HUTANG : } \\
\hline KAS $\ldots \ldots \ldots \ldots \ldots \ldots \ldots \ldots$ & $\ldots \ldots$ & HUTANG DAGANG......... & RP. 3.500 .000 \\
\hline RP.16.600.000 & & & \\
\hline PITANG DAGANG .......... & & & \\
\hline 1.500 .000 & & & \\
\hline PERSEDIAAN BARANG. & 22.250 .000 & & \\
\hline ALAT-ALAT TOKO.......... & & & \\
\hline$\underline{2.500 .000}$ & & MODAL : & \\
\hline & & $\begin{array}{l}\text { MODAL NY. FINA......... } \\
30.000 .000\end{array}$ & RP. \\
\hline TOT AKT . LANCAR & RP.42.600.000 & & \\
\hline AKTIVA TETAP : & & MODAL TN. RISKY...... & RP. 24.000 .000 \\
\hline TANAH................... & RP. & MODAL NN. RAHMA... & RP. 19.000 .000 \\
\hline 8.400 .000 & & MODAL TN. ARPRA........ & $\underline{\mathrm{RP}}$. \\
\hline BANGUNAN............... & & 6.500 .000 & \\
\hline 6.000 .000 & & & \\
\hline KENDARAAN.... & & TOTAL MODAL............. & \\
\hline 18.000 .000 & & RP.79.500.000 & \\
\hline $\begin{array}{l}\text { PERALATAN KANTOR.. } \\
\underline{8.000 .000}\end{array}$ & & JML HUT DAN MODAL & RP.83.000.000 \\
\hline $\begin{array}{l}\text { TOT AKTIVA TETAP... } \\
40.000 .000 \\
\end{array}$ & $\underline{\mathrm{RP}}$. & & \\
\hline JML AKTIVA & RP. 83.000.000 & & \\
\hline
\end{tabular}




\section{Firma Didirikan Oleh Anggota-Anggota yang Semuanya Sudah Memiliki Usaha}

Prosedur akuntansi yang digunakan untuk mencatat pendirian firma pada dasarnya sama dengan dua kemungkinan pendirian firma yang telah dibahas dimuka.

Prosedur akuntansi yang harus ditempuh terlebih dahulu adalahdiadakan penilaian-penilaian kembali masing-masing kekayaannya, kemungkinan ada dua metode pembukuan yang dapat digunakan yaitu menggunakan buku baru ataukah melanjutkan pembukuan salah seorang anggota.

\section{Contoh 3:}

Tuan Rahmad \& Tuan Mahmud bersepakat akan mendirikan Firma " RAHMA". Tuan Rahmad sebelumnya sudah mempunyai usaha dagang yang cukup berhasil \& pada saat akan mendirikan firma, posisi keuangan milik Tuan Rahmad menunjukkan data sbb:

\section{Neraca Tuan RAHMAD}

\begin{tabular}{|c|c|}
\hline $\begin{array}{l}\text { Kas................... } \\
3.200 .000\end{array}$ & $\begin{array}{l}\text { Hutang Dagang................ Rp } \\
4.675 .000\end{array}$ \\
\hline $\begin{array}{l}\text { Piutang Dagang } \ldots \ldots \ldots \ldots . . \mathrm{Rp} \\
5.850 .000\end{array}$ & $\begin{array}{l}\text { Hutang Lain-lain.............. Rp } \\
2.325 .000\end{array}$ \\
\hline $\begin{array}{l}\text { Kendaraan...................Rp } 8.800 .000 \\
\text { Persd. Brg. Dag .......... Rp } \\
\underline{10.450 .000}\end{array}$ & $\begin{array}{l}\text { Modal Tn. Rahmad } \ldots \ldots \ldots \ldots, \underline{R p} \\
\underline{21.300 .000} \\
\text { Jumlah........................ Rp } \\
28.300 .000\end{array}$ \\
\hline $\begin{array}{l}\text { Jumlah................... Rp } \\
28.300 .000\end{array}$ & \\
\hline
\end{tabular}


Demikian pula Tn. Mahmud sudah mempunyai usaha dagang yang pada saat pendirian firma mempunyai posisi keuangan sbb:

Neraca Tuan Mahmud

\begin{tabular}{|c|c|}
\hline 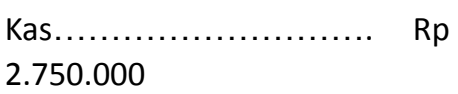 & $\begin{array}{l}\text { Hutang Dagang...............Rp } \\
2.860 .000\end{array}$ \\
\hline $\begin{array}{l}\text { Piutang lain-lain....... Rp } \\
6.850 .000\end{array}$ & $\begin{array}{l}\text { Hutang Bank.................. Rp } \\
6.740 .000\end{array}$ \\
\hline $\begin{array}{l}\text { Peralatan toko.......... Rp } \\
5.500 .000\end{array}$ & $\begin{array}{l}\text { Modal Tn. Mahmud......... } \underline{\text { Rp }} \\
\underline{12.800 .000}\end{array}$ \\
\hline $\begin{array}{l}\text { Bangunan.............. } \\
\underline{7.300 .000}\end{array}$ & $\begin{array}{l}\text { Jumlah........................... Rp } \\
22.400 .000\end{array}$ \\
\hline $\begin{array}{l}\text { Jumlah ................... } \\
22.400 .000\end{array}$ & \\
\hline
\end{tabular}

Kesepakatan yang dibuat antara Tuan Rahmad \& Tuan Mahmud sebelum pendirian Firma adalah sbb:

1. Kas Tn. Rahmad diambil sebesar Rp 1.500.000, sedangkan kas milik Tn. Mahmud diambil semua

2. Piutang dagang Tn. Rahmad hanya diserahkan sebagian saja, demikian pula persediaan barang dagangannya

3. Peralatan toko Tn. Mahmud dinaikkan nilainya sebesar Rp 600.000 , demikian pula bangunan miliknya dinilai sebesar nilai wajarnya menjadi Rp 8.800 .000

4. Hutang dagang Tn. Rahmad akan dilunasi semuanya, sedangkan Hutang Bank Tn. Mahmud akan dilunasi sebagian.

Pembukuan menggunakan Buku Baru

Pembukuan melanjutkan Buku Tn. Rahmad

1. Membuat Jurnal penyesuaian kekayaan Tn. Rahmad \& Tn. Mahmud 


\begin{tabular}{|c|c|}
\hline 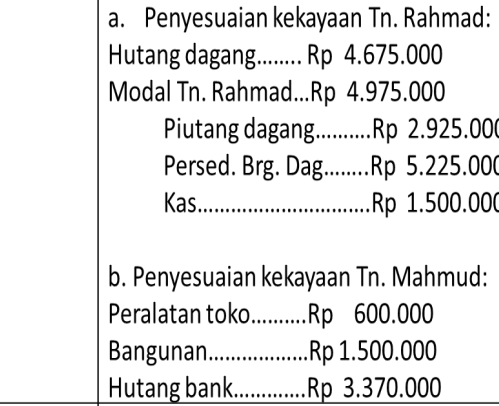 & 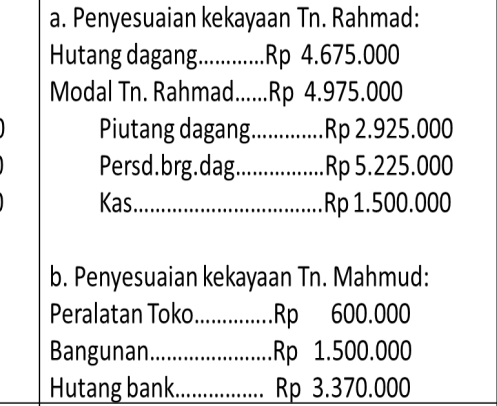 \\
\hline \multicolumn{2}{|c|}{ 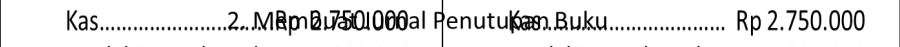 } \\
\hline 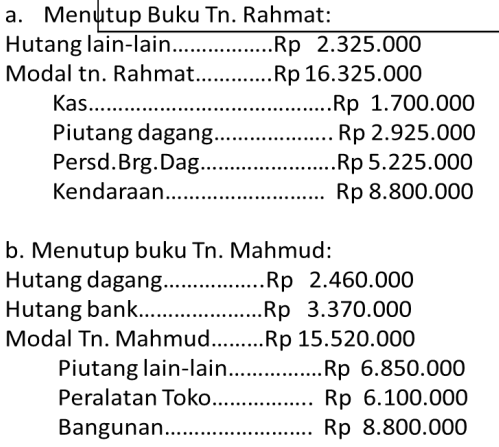 & $\begin{array}{l}\text { b. Menutup buku Tn. Mahmud: } \\
\text { Hutang dagang..............Rp } 2.460 .000 \\
\text { hutang bank.............. Rp } 3.370 .000 \\
\text { Modal Tn. Mahmud......Rp } 15.520 .000 \\
\text { Piutang lain-lain...........Rp } 6.850 .000 \\
\quad \text { Peralatan Toko..............Rp } 6.100 .000 \\
\text { Bangunan......................Rp } 8.800 .000\end{array}$ \\
\hline \multicolumn{2}{|c|}{$\begin{array}{l}\text { Selanjutnya dibuatlah NERACA AWAL PENDIRIAN FIRMA. Ne } \\
\text { awal pendirian firma "RAHMA" baik dengan mengguna } \\
\text { metode pembukuan dengan buku baru maupun mengguna } \\
\text { pembukuan melanjutkan buku Tn. Rahmad sbb: }\end{array}$} \\
\hline
\end{tabular}




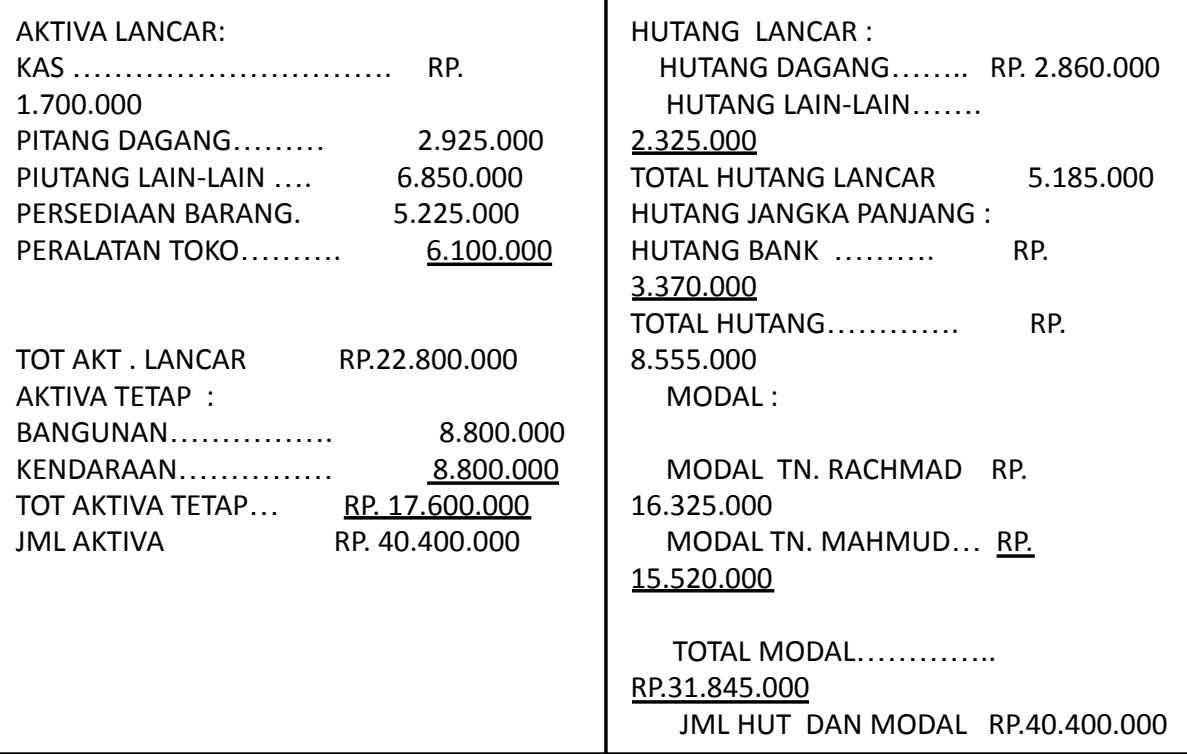

BAB 3

Pembagian Laba Rugi Firma

\section{Capaian Pembelajaran (CP):}

a. Mahasiswa dapat memahami dan menjelaskan prosedur akuntansi dan perhitungan pembagian Laba Rugi Firma dengan menggunakan berbagai macam metode pembagian Laba Rugi

b. Mahasiswa dapat mengaplikasikan pembagian laba rugi firma dengan berbagai macam metode.

\section{A. Laba Rugi Dibagi Sama}

Apabila laba rugi dibagi sama, maka ini berarti setiap anggota akan memperoleh hak atas laba atau rugi tersebut sama besar. Dalam contoh no.4 diatas, laba firma adalah 
sebesar Rp 60.000.000 \& laba ini akan dibagi sama rata kepada Tn. A, Tn. B, \& Tn. C sehingga masing-masing anggota akan menerima hak atas laba firma sebesar :

$\underline{\text { Rp } 60.000 .000}=R p 20.000 .000$

3

Jurnal pembagian laba tahun 20XY sbb:

Laba Rugi

Modal Tn. A

Modal Tn. B

Modal Tn. C
Rp 60.000.000

Rp 20.000.000

Rp 20.000.000

Rp 20.000.000

\section{B. Laba Rugi Dibagi Berdasarkan Perbandingan Tertentu yang telah Disepakati}

Dalam hal pembagian Laba Rugi dengan kesepakatan ini, maka pembagian tersebut harus tercantum dalam akte pendirina Firma agar dapat dijamin oleh hukum. Perbandingan pembagian laba rugi tersebut harus dicantumkan dengan jelas, baik berupa angka perbandingan maupun prosentase perbandingan (misalnya 1:2:3 atau 20\%:40\%:40\%).

Misalnya: Tn. A, Tn. B, \& Tn. C sudah bersepakat bahwa laba atau rugi yang diperoleh Firma akan dibagi dengan perbandingan 3:1:2, maka jurnal \& perhitungan pembagian laba firma tersebut adalah sbb:

Hak Laba untuk Tn. A :

$$
=\quad 3 \times R \text { R } 60.000 .000=R p 30.000 .000
$$

$$
3+1+2
$$

Hak Laba untuk Tn. B :

$$
=\quad \begin{gathered}
1 \\
3+1+2
\end{gathered} \quad X \operatorname{Rp} 60.000 .000=R p 10.000 .000
$$

Hak Laba untuk Tn. C :

$$
=\quad \begin{gathered}
2 \\
3+1+2
\end{gathered} \times \operatorname{Rp} 60.000 .000=\underline{\operatorname{Rp~20.000.000}}
$$


Jumlah

Rp 60.000.000

Jurnal pembagian Laba Firma sbb:

Laba Rugi

Rp 60.000.000

Modal Tn. A

Rp 30.000.000

Modal Tn. B

Rp 10.000 .000

Modal Tn. C

Rp 20.000.000

Dengan adanya pembagian laba firma sesuai dengan perbandingan diatas, maka rekening modal masing-masing anggota akan bertambah sebesar hak atas labanya masing-masing sbb:

\begin{tabular}{|l|l|l|ll|}
\hline Rek. Modal $=$ & $\underline{\text { Modal Awal }+}$ & $\underline{\text { Hak Atas Laba }}$ & \multicolumn{2}{|c}{ Modal Akhir } \\
Tuan A & Rp 20.000.000 & Rp 30.000.000 & Rp 50.000 .000 \\
Tuan B & Rp 10.000.000 & Rp 10.000.000 & Rp 20.000 .000 \\
Tuan C & Rp 15.000.000 & Rp 20.000.000 & Rp 35.000 .000 \\
Jumlah & Rp 45.000.000 & Rp 60.000.000 & Rp 105.000 .000 \\
\hline
\end{tabular}

Apabila perbandingan dalam bentuk prosentase, misalnya saja pembagian laba firma tersebut untuk Tn. A, Tn. B, \& Tn. C dibagi dengan perbandingan 30\% : 25\% :45\%, maka perhitungan pembagian laba firma sbb:

Hak Laba untuk Tn. A=30\% x Rp 60.000.000 = Rp 18.000.000 Hak Laba untuk Tn. B= 25\% x Rp 60.000.000 = Rp 15.000.000 Hak Laba untuk Tn. C=45\% x Rp 60.000.000 = $\underline{\text { Rp 27.000.000 }}$

$$
\text { Jumlah }=
$$

60.000 .000

Jurnal pembagian Laba Rugi sbb:

Laba Rugi

Rp 60.000.000

Modal Tn. A

Rp 18.000.000

Modal Tn. B

Rp 15.000.000

Modal Tn. C

Rp 27.000.000 


\section{Laba Rugi Dibagi Sesuai dengan Perbandingan Modal Awal}

Apabila Laba - Rugi Firma dibagi sesuai dengan perbandingan modal awal masing - masing anggota, maka yang dijadikan pedoman pembagian adalah jumlah modal awal masing-masing anggota yang tampak dalam Neraca Awal Firma. Jika Firma tersebut sudah berjalan selama beberapa tahun, maka yang dimaksud modal awal adalah saldo modal masing-masing anggota pada awal tahun.

Dengan menggunakan contoh sebelumnya, modal awal masing-masing anggota Firma beserta perhitungan hak atas laba berdasarkan rasio modal awal sbb:

\begin{tabular}{|c|c|c|c|}
\hline Nama & Saldo Modal & Rasio Pembagian & Hak atas \\
\hline Anggota & Awal & Laba & \\
\hline Tn. A & Rp 20.000.000 & $20 / 45$ & $\overline{20 / 45} \times \operatorname{Rp} 60.000 .000=\operatorname{Rp} 26.666 .670$ \\
\hline Tn. B & $\operatorname{Rp} 10.000 .000$ & $10 / 45$ & $10 / 45 \times \operatorname{Rp} 60.000 .000=\operatorname{Rp} 13.333 .370$ \\
\hline Tn. C & $\begin{array}{l}\text { Rp } 15.000 .000 \\
\text { Rp } 45.000 .000\end{array}$ & $15 / 45$ & $\frac{15 / 45 \times \operatorname{Rp} 60.000 .000=\operatorname{Rp} 20.000 .000}{\operatorname{Rp} 60.000 .000}$ \\
\hline
\end{tabular}

Jurnal pembagian Laba - Rugi Firma sbb:
Laba - Rugi
Rp 60.000.000
Modal Tn. A
Rp 26.666.670
Modal Tn. B
Rp 13.333.330
Modal Tn. C
Rp 20.000.000

Bila dimasukkan dalam tabel, akan tampak sbb: 


\begin{tabular}{|l|l|l|l|}
\hline Rekening Modal $=$ & $\underline{\text { Modal Awal }+}$ & $\underline{\text { Hak Atas Laba }=}$ & $\underline{\text { Modal Akhir }}$ \\
Tuan A & Rp 20.000.000 & Rp 26.666.670 & Rp 46.666.670 \\
Tuan B & Rp 10.000.000 & Rp 13.333.330 & Rp 23.333.330 \\
Tuan C & $\underline{\text { Rp } 15.000 .000}$ & $\underline{\text { Rp 20.000.000 }}$ & $\underline{\operatorname{Rp~35.000.000~}}$ \\
Jumlah & Rp 45.000.000 & Rp 60.000.000 & Rp 105.000.000 \\
\hline
\end{tabular}

D. Laba Rugi Dibagi Sesuai dengan Perbandingan Modal Akhir Apabila Modal akhir dipakai sebagai dasar pembagian Laba - Rugi Firma, maka diperhitungkan mutasi modal masing-masing anggota sampai pada saat pembagian Laba dilakukan. Dengan menggunakan contoh sebelumnya, maka besarnya modal akhir masing-masing anggota dihitung atau dilihat dalam buku besar rekening modalnya masing-masing sbb:

Modal Tuan A

\begin{tabular}{|c|c|c|c|c|c|}
\hline$\underline{\text { Tanggal }}$ & $\underline{\text { Keterangan }}$ & \multicolumn{2}{|c|}{ Mutasi } & Saldo Awal & $\underline{\mathrm{D} /}$ \\
\hline $\begin{array}{l}1 \text { Feb } 20 X Y \\
3 \mathrm{Mei} \\
20 \mathrm{XY} \\
5 \mathrm{Nov} \\
20 \mathrm{XY}\end{array}$ & $\begin{array}{l}\text { Penyetoran Modal } \\
\text { Awal } \\
\text { Pengambilan untuk } \\
\text { Prive } \\
\text { Penyetoran Uang }\end{array}$ & $\begin{array}{l}\underline{\text { Debet }} \\
- \\
5.000 .000 \\
-\end{array}$ & $\begin{array}{l}\frac{\text { Kredit }}{20.000 .000} \\
- \\
6.000 .000\end{array}$ & $\begin{array}{r}20.000 .000 \\
15.000 .000 \\
21.000 .000\end{array}$ & $\begin{array}{l}\underline{\Lambda} \\
\mathrm{K} \\
\mathrm{K} \\
\mathrm{K}\end{array}$ \\
\hline
\end{tabular}

Modal Tuan B

\begin{tabular}{|c|c|c|c|c|c|}
\hline \multirow[t]{2}{*}{$\underline{\text { Tanggal }}$} & \multirow[t]{2}{*}{$\underline{\text { Keterangan }}$} & \multicolumn{2}{|c|}{ Mutasi } & \multirow[t]{2}{*}{ Saldo Awal } & \multirow[t]{2}{*}{$\underline{D} / K$} \\
\hline & & Debet & Kredit & & \\
\hline 1 Feb $20 X Y$ & $\begin{array}{l}\text { Penyetoran Modal } \\
\text { Awal }\end{array}$ & - & 10.000 .000 & 10.000 .000 & K \\
\hline $2 \mathrm{Apr} 20 \mathrm{XY}$ & $\begin{array}{l}\text { Penyetoran } \\
\text { Kekayaan }\end{array}$ & - & 4.000 .000 & 14.000 .000 & K \\
\hline 1 Jul 20XY & Pengambilan & 3.000 .000 & - & 11.000 .000 & K \\
\hline
\end{tabular}


Modal Tuan C

\begin{tabular}{|c|c|c|c|c|c|}
\hline \multirow[t]{2}{*}{$\underline{\text { Tanggal }}$} & \multirow[t]{2}{*}{ Keterangan } & \multicolumn{2}{|c|}{ Mutasi } & \multirow[t]{2}{*}{$\underline{\text { Saldo Awal }}$} & \multirow[t]{2}{*}{$\underline{D} / K$} \\
\hline & & Debet & Kredit & & \\
\hline 1 Feb 20XY & $\begin{array}{l}\text { Penyetoran Modal } \\
\text { Awal }\end{array}$ & - & 15.000 .000 & 15.000 .000 & K \\
\hline $1 \mathrm{Jul} 20 \mathrm{XY}$ & $\begin{array}{l}\text { Penyetoran } \\
\text { Kekayaan }\end{array}$ & - & 3.000 .000 & 18.000 .000 & K \\
\hline 5 Nov $20 X Y$ & Pengambilan & 4.000 .000 & - & 14.000 .000 & K \\
\hline
\end{tabular}

Setelah saldo modal akhir Tn. A, B, \& C diketahui dalam rekening buku besarnya masing-masing, langkah selanjutnya adalah membuat perhitungan pembagian Laba Firma sbb:

\begin{tabular}{|c|c|c|c|}
\hline Nama & Saldo Modal & Rasio Pembagian & Hak atas Laba \\
\hline Anggota & Akhir & $\underline{\text { Laba }}$ & $21 / 46 \times \operatorname{Rp} 60.000 .000=\operatorname{Rp} 27.381 .300$ \\
\hline Tn. A & Rp 21.000.000 & $21 / 46$ & $11 / 46 \times \operatorname{Rp} 60.000 .000=\operatorname{Rp} 14.347 .800$ \\
\hline Tn. B & Rp 11.000 .000 & $11 / 46$ & $14 / 46 \times \operatorname{Rp} 60.000 .000=\operatorname{Rp} 18.260 .900$ \\
\hline Tn. C & $\begin{array}{l}\text { Rp 14.000.000 } \\
\operatorname{Rp~46.000.000}\end{array}$ & $14 / 46$ & Rp 60.000.000 \\
\hline
\end{tabular}

Jurnal pembagian Laba Firma sbb:
Laba - Rugi
Rp 60.000.000
Modal Tn. A
Rp 27.391.300
Modal Tn. B
Rp 14.347.800
Modal Tn. C
Rp 18.260.900 
Dengan adanya pembagian laba tersebut, maka saldo modal masing-masing anggota akan menjadi:

\begin{tabular}{|l|l|l|l|}
\hline Nama Anggota & Modal Akhir + & Hak atas Laba $=$ & Modal Akhir Setelah Laba \\
Tn. A & Rp 21.000 .000 & Rp 27.391 .300 & Rp 48.391.300 \\
Tn. B & Rp 11.000 .000 & Rp 14.347 .800 & Rp 25.347.800 \\
Tn. C & $\underline{\text { Rp } 14.000 .000}$ & $\underline{\text { Rp } 18.260 .900}$ & $\underline{\text { Rp } 32.260 .900}$ \\
Jumlah & Rp 46.000.000 & Rp 60.000 .000 & Rp 106.000 .000 \\
\hline
\end{tabular}

\section{E. Laba Rugi Dibagi Sesuai dengan Perbandingan Modal Rata-Rata}

Apabila modal rata-rata yang digunakan sebagai dasar pembagian laba - rugi firma, maka langkah yang ditempuh adalah menghitung modal rata-rata dengan berpegang pada mutasi modal yang dapat dilihat dalam buku besar modal masing-masing anggota. Dengan menggunakan contoh sebelumnya, maka perhitungan modal rata-rata akan tampak sbb:

Modal Tuan A:

\begin{tabular}{|c|c|c|c|}
\hline Masa Modal & Jumlah & Modal yang ditanamkan & Modal Akhir Setelah \\
\hline ditanamkan & Bulan & Rp 20.000.000 & Laba \\
\hline & 3 Bulan & Rp 15.000.000 & Rp 60.000.000 \\
\hline $3 \mathrm{Mei}-5 \mathrm{Nov}$ & 6 Bulan & $\underline{\operatorname{Rp} 21.000 .000}$ & $\mathrm{Rp} 90.000 .000$ \\
\hline 5 Nov - 31 Des & $\begin{array}{l}2 \text { Bulan } \\
11 \text { Bulan }\end{array}$ & & $\begin{array}{l}\mathrm{Rp} \mathrm{42.000.000} \\
\operatorname{Rp} 192.000 .000\end{array}$ \\
\hline
\end{tabular}


Modal rata-rata Tuan A $=\underline{\operatorname{Rp} 192.000 .000}$

11

$=\operatorname{Rp} 17.454 .540$

Modal Tuan B:

Perhitungan modal rata-rata $\mathrm{Tn}$. B dapat menggunakan cara seperti pada perhitungan modal rata-rata Tuan A. Tetapi utnuk memberikan alternatif cara perhitungan yang lain kepada mahasiswa, dapat pula digunakan cara sbb:

\begin{tabular}{|c|c|c|}
\hline Modal vang ditanam $X$ & Jumlah Bulan $=$ & Jumlai Modal dalam Jangka Penanaman \\
\hline - $\quad \operatorname{Rp} 10.000 .000$ & $\times 2$ bulan ( 1 Feb -2 April) & $=\operatorname{Rp} \quad 20.000 .000$ \\
\hline - $\quad \operatorname{Rp} 14.000 .000$ & X 3 bulan ( 2 April - 1 Juli) & $=\operatorname{Rp} \quad 42.000 .000$ \\
\hline Rp 11.000 .000 & X 6 bulan ( 1 Juli - 31 Des) & $=\mathrm{Rp} \quad 66.000 .000$ \\
\hline & 11 Bulan & Rp 128.000 .000 \\
\hline
\end{tabular}

Modal rata-rata Tn. $B=\underline{\operatorname{Rp} 128.000 .000}=\operatorname{Rp} 11.636 .360$

Modal Rata-rata Tn. C :

Perhitungan modal rata-rata Tn. $\mathrm{C}$ dapat menggunakan cara seperti pada perhitungan modal rata-rata Tn. A \& Tn. B di atas. Tetapi untuk memberikan alternatif cara perhitungan yang lain kepada para mahasiswa dapat pula digunakan cara perhitungan sbb:

$\underline{(5 \times 15.000 .000)+(4 \times 18.000 .000)+(2 \times 14.000 .000)}$ 11

$=\operatorname{Rp} 15.909 .000$

Ket: Angka 5 pada rumus diatas menunjukkan masa modal Tn. C ditanamkan dalam bulan, yaitu mulai tgl 1 Feb $20 X Y-1$ 
Juli 20XY. Demikian pula angka 4 \& 2 yang merupakan jumlah penanaman.

Setelah modal rata-rata masing-masing anggota dihitung, maka langkah selanjutnya adalah menghitung hak laba masing-masing anggota dengan berdasarkan perbandingan modal rata-rata tsb sbb:

\begin{tabular}{|c|c|c|c|}
\hline Nama Anggota & Modal Rata-rata & Hak Atas Lab & \\
\hline Tn. A & Rp 17.454.540 & 17.454 .540 & $X \operatorname{Rp} 60.000 .000=\operatorname{Rp} 23.727 .725$ \\
\hline Tn. B & Rp 11.636.360 & 44.999 .990 & \\
\hline \multirow[t]{5}{*}{ Tn. C } & $\underline{\operatorname{Rp} 15.909 .000}$ & 11.636 .360 & $X \operatorname{Rp} 60.000 .000=R p 15.515 .150$ \\
\hline & Rp 44.999.909 & 44.999.990 & \\
\hline & & $\underline{15.909 .000}$ & $X \operatorname{Rp} 60.000 .000=\underline{R p 21.212 .125}$ \\
\hline & & 44.999 .990 & \\
\hline & & & $=\operatorname{Rp} 60.000 .000$ \\
\hline
\end{tabular}

Jurnal pembagian Laba Firma adalah sbb:

Laba-Rugi

Modal Tn. A

Modal Tn. B

Modal Tn. C
Rp 60.000.000

Rp 23.272.725

Rp 15.515.150

Rp 21.212.125

Dengan adanya pembagian laba firma tsb, maka saldo masing-masing anggota akan bertambah sebesar haknya atas laba masing-masing anggota.perlu dicatat disini bahwa untuk menghitung modal rata-rata dapat menggunakan salah satu cara dari tiga cara yang diuraikan di muka, tinggal memilih cara mana yang paling mudah digunakan. 


\section{F. Laba Rugi Dibagi Sama Setelah Dikurangi Gaji dan Bonus}

Apablila laba-rugi firma dibagi setelah dikurangi gaji $\&$ bonus, maka yang akan mnenjadi hal penting disini adalah jumlah gaji \& bonus kepada para anggota. Dalam hal ini terlebih dahulu ditetapkan besarnya gaji (misal, gaji bulanan) kepada para anggota \& juga diperhitungkan adanya bonus kepada anggota. Setelah gaji \& bonus ditetapkan jumlahnya, jumlah gaji \& bonus tersebut mengurangi laba-rugi firma \& sisa laba dikurangi gaji \& bonus tersbut barulah dibagikan kepada para anggota sesuai dengan keputusan yang telah disetujui.

Apabila laba rugi firma dibagi setelah dikurangi gaji dan bonus, maka yang menjadi hal penting disini adalah jumlah gaji dan bonus kepada para anggota. Dengan menggunakan contoh 4 . dimuka

\begin{tabular}{|l|l|l|}
\hline Nama Anggota & gaji bulanan & Bonus \\
\hline Tuan A & Rp. 400.000 & $8 \%$ dari laba \\
\hline Tuan B & Rp 350.000. & Rp 1.800.000 \\
\hline Tuan C & Rp 500.000 & Rp 3.650.000 \\
\hline
\end{tabular}

Berdasarkan gaji dan bonus tersebut, dapat dibuat perhitunggan sbg berikut:

\begin{tabular}{|l|l|l|l|l|}
\hline & Tuan A & Tuan B & Tuan C & JUMLAH \\
\hline $\begin{array}{l}\text { GAJI PEMILIK } \\
(11 \text { BULAN })\end{array}$ & 4.400 .000 & 3.850 .000 & 5.500 .000 & 13.750 .000 \\
\hline
\end{tabular}




\begin{tabular}{|l|l|l|l|l|}
\hline BONUS & 4.800 .000 & 1.800 .000 & 3.650 .000 & 10.250 .000 \\
\hline JUMLAH & 9.200 .000 & 5.650 .000 & 9.150 .000 & 24.000 .000 \\
\hline
\end{tabular}

Berdasarkan perhitungan diatas, jumlah gaji \& bonus untuk para anggota adalah $\mathrm{Rp}$ 24.000.000. dengan demikian sisa yang akan dibagikan para anggota adalah sebesar $\mathrm{Rp}$ 60.000.000 - Rp 24.000.000 = Rp 36.000.000. Sisa laba sebesar Rp 36.000.000 tesebut selanjutnya dibagi sanma rata kepada para anggota yaitu masing-masing sebesar Rp 12.000.000. Akibat dari perhitungan di atas, maka laba sebesar $\mathrm{Rp}$ 60.000.000 akan dibagikan kepada para anggota sbb:

Tn. A = Rp 9.200.000 + $\underline{36.000 .000}=\operatorname{Rp~21.200.000~}$

3

Tn. $B=\operatorname{Rp} 5.650 .000+\underline{36.000 .000}=\operatorname{Rp} 17.650 .000$

3

Tn. $C=\operatorname{Rp} 9.150 .000+\underline{36.000 .000}=\underline{\operatorname{Rp} 21.150 .000}$

3

Jumlah $=$ Rp 60.000.000

Jurnal pembagian laba sbb:

Laba - Rugi

Modal Tn. A

Modal Tn. B

Modal Tn. C
Rp 60.000.000

Rp 21.200.00

Rp 17.650.000

Rp 21.150.000

G. Laba Rugi Dibagi Sama Setelah Dikurangi Bunga Modal Rata-Rata

Dalam pembagian laba rugi dibagi sama setelah dikurangi bunga modal rata-rata ini terlebih dahulu harus ditentukan besarnya bunga modal rat-rata untuk masing-masing anggota. Setelah jumlah bunga modal rata-ratra ditentukan, barulah laba yang diperoleh firma dikurangi dengan jumlah 
bunga modal rata-rata tersebut dan sisa laba kemudian dibagikan kepada para anggota sesuai dengan ketentuan. Dengan menggunakan contoh 4 dimuka apabila ditentukan bawa besarnya bunga modal rata-rata untuk masing-masing anggota adalah 9\%, maka besarnya bunga modal rata-rata masing-masing anggota dapat di hitung sebagai berikut :

Tn A= 9\% x Rp. $17.454 .540 *$ ) = Rp. 1.570 .900 (pembulatan) Tn $B=9 \% \times$ Rp. 11.636.360 *) = Rp. 1.047.200 (Pembulatan) Tn. $B=9 \% \times$ Rp $15.909 .090^{*}$ ) = Rp. 1.431 .800 (Pembulatan)

$$
\text { Jumlah = Rp. 4.049.900 }
$$

*) lihat perhitungan modal rata-rata pada bahasan dimuka.

Sisa laba setelah modal rata-rata adalah :

$$
\text { Rp. 60.000.000 -Rp. } 4.049 .000=\text { Rp.55.950.100 }
$$

Dengan demikian maka hak laba untuk masing-masing anggota adalah sebagai berikut :

Tn. A =Rp.1.570.900+Rp. $\underline{55.950 .100=R p .20 .220 .930 ~}$

3

Tn. $B=$ Rp.1.047.200+Rp. $\underline{55.950 .100=R p} \cdot 19.697 .230$

3

Tn. $C=$ Rp. $1.431 .800+$ Rp. $\underline{55.950 .100=R p} \cdot 20.081 .840$

$$
3
$$$$
\text { Jumlah = Rp. 60.000.000 }
$$

Jurnal pembagian laba firma adalah sebagai berikut: Laba Rugi..........Rp. 60.000.000

Modal Tn A........................Rp. 20.220.930

Modal Tn B......................Rp. 19.697.230

Modal Tn C.......................Rp. 20.081.840 


\section{BAB 4}

\section{Akuntansi Untuk Perubahan Pemilikan Persekutuan}

\section{Capaian Pembelajaran (CP):}

a. Mahasiswa dapat memahami beberapa alasan yang mendasari terjadinya perubahan pemilikan firma dan jenis perubahan pemilikan firma

b. Mahasiswa dapat memahami proses pencatatan dan perhitungannya jika terjadi ada anggota baru yang masuk menjadi anggota firma, baik dengan cara membeli hak anggota lama maupun dengan cara menyetorkan uang sebagai investasinya dalam firma

c. Mahasiswa dapat memahami proses pencatatan dan perhitungannya jika ada anggota firma yang keluar karena mengundurkan diri atau meninggal dunia

d. Mahasiswa dapat memahami penggunaan metode bonus dan atau metode goodwill dalam proses pencatatan perubahan pemilikan firma

Perubahan pemilikan firma terjadi karena adanya perubahan dalam keanggotaan firma. Perubahan keanggotaan firma dapat terjadi karena adanya anggota baru yang masuk menjadi anggota firma atau adanya anggota firma yang keluar atau meninggal dunia. Dengan adanya perubahan tersebut, berarti anggota firma sudah berbeda dengan saat pendirian \& akibatnya firma tersebut sudah berubah pemiliknya sehingga sesuai dengan karakteristik firma (limited life), secara hukum, firma sudah dianggap bubar walaupun secara ekonomis firma tersebut masih melanjutkan usahanya. 
Akuntansi perubahan pemilikan firma akan membahas mengenai 2 kemungkinan yang menjadi penyebab perubahan pemilikan firma, yaitu:

1. Perubahan pemilikan firma akibat adanya anggota baru yang masuk

2. Perubahan pemilikan firma akibat adanya anggota yang keluar atau meninggal dunia.

\section{A. Perubahan Pemilikan Firma Akibat Adanya Anggota Baru yang Masuk}

Apabila ada anggota baru yang masuk menjadi anggota firma, maka pemilik firma akan mengalami perubahan, demikian pula dalam hal pembagian Laba Rugi mengalami perubahan pula. Masuknya anggota baru firma tersebut dapat dilakukan dengan melalui cara-cara sbb:

a. Membeli hak anggota lama

b. Memasukkan kekayaan (investasi ) kepada firma.

\section{Membeli Hak Anggota Lama}

Apabila anggota baru masuk menjadi anggota firma dengan cara mengganti atau membeli hak anggota lama, maka transaksi jual beli tersebut tidak akan mempengaruhi modal firma, sebab transaksi jual beli tersebut adalah merupakan transaksi pribadi antara anggota baru dengan anggota lama yang menjual haknya. Dalam hal ini firma hanya mencatat pemindahan modal dari anggota lama kepada anggota baru \& juga mencatat mengenai hak atas laba - rugi anggota baru tersebut. Kemudian untuk prosedur hukumnya, para anggota firma segera membuat akte pendirian baru. 
Firma "PQR"

Neraca

31 Maret 20XY

\begin{tabular}{|c|c|}
\hline 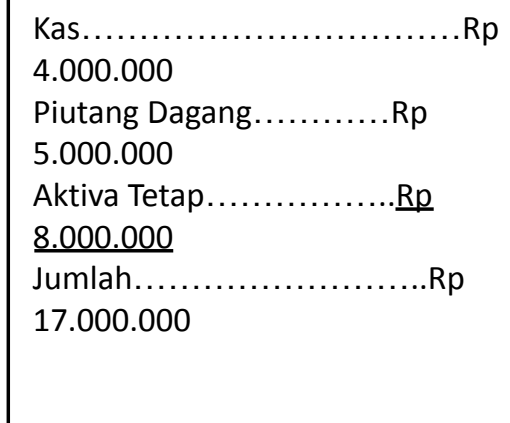 & 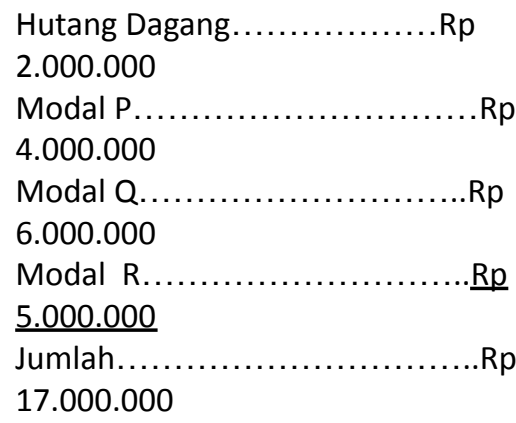 \\
\hline
\end{tabular}

\section{Kasus 1:}

Tuan $S$ ingin masuk menjadi anggota firma dengan cara membeli hak Tuan $R$ dengan sejumlah pembayaran $R p$ 7.250.000. Jurnal yang dibuat oleh firma dengan adanya transaksi tersebut sbb:

Modal Tuan R Rp 5.000.000

\section{Modal Tuan S}

Rp 5.000.000

(Mencatat pemindahan hak pemilikan Tuan $\mathrm{R}$ ke Tuan $\mathrm{S}$ sebesar saldo modal Tuan R).

Setelah dijurnal oleh firma, maka Tuan $R$ sudah tidak mempunyai hak pemilikan lagi terhadap firma karena hak kepemilikannya sudah dibeli oleh Tuan S. Mengenai besarnya uang kas yang diserahkan untuk membeli hak Tuan $\mathrm{R}$, tidak perlu dicatat oleh firma sebab transaksi penerimaan kas dari Tuan $\mathrm{S}$ ke 
Tuan $\mathrm{R}$ adalah urusan pribadi mereka, bukan urusan firma. Akibatnya pemilik firma sekarang adalah Tuan $P, Q, \&$ S. Jumlah modal firma tidak berubah.

\section{Kasus 2}

Tuan $\mathrm{M}$ ingin masuk menjadi anggota firma dengan cara membeli $1 / 4$ bagian hak Tuan P \& $3 / 4$ bagian hak Tuan $Q$. dengan adanya transaksi ini, maka hak Tuan $\mathrm{P}$ akan berkurang $1 / 4$ \& hak Tuan $Q$ akan berkurang $3 / 4$ bagian. Jurnal yang dibuat $s b b$ :

Modal Tn.P

Modal Tn.Q Modal Tn.M
Rp 1.000.000

Rp 4.500.000

Rp 5.500.000

\section{Perhitungan:}

- $\quad$ Modal Tn.P di (D) = 1/4 X Rp 4.000.000 = Rp 1.000.000

- $\quad$ Modal Tn.Q di (D) = 3/4 XRp 6.000.000 = Rp 4.500 .000

Dengan masuknya Tn.M menjadi anggota firma, maka di dalam firma tidak mengalami perubahan di dalam jumlah modal, hanya saja komposisi modal akan berubah sbb:

\begin{tabular}{|l|c|l|l|}
\hline Nama Anggota & \multicolumn{3}{|c|}{ Jumlah Modal } \\
\hline & \multicolumn{2}{|c|}{ Sebelum Masuknya Tn. M } & Sesudah Masuknya Tn. M \\
\hline Modal Tuan P & $\mathrm{Rp} 4.000 .000$ & $\mathrm{Rp}$ & 3.000 .000 \\
\hline Modal Tuan Q & $\mathrm{Rp} 6.000 .000$ & $\mathrm{Rp} \quad 1.500 .000$ \\
\hline Modal Tuan S & $\mathrm{Rp} 5.000 .000$ & $\mathrm{Rp} \quad 5.000 .000$ \\
\hline Modal Tuan M & \multicolumn{2}{|c|}{-} & $\mathrm{Rp} \quad 5.500 .000$ \\
\hline Jumlah & $\mathrm{Rp} 15.000 .000$ & $\mathrm{Rp} 15.000 .000$ \\
\hline
\end{tabular}

Setelah anggota baru masuk menjadi anggota, langkah selanjutnya adalah membuat perjanjian pembagian laba rugi firma. Untuk kasus no. 1 pada contoh di atas Tuan $S$ masuk 
menggantikan hak Tuan $\mathrm{R}$, tidak terjadi masalah tentang pembagian Laba-Rugi, sebab otomatis semua hak Tuan $R$ terhadap firma akan menjadi hak Tuan S.

Untuk kasus no. 2, terjadi permasalahan terhadap pembagian laba rugi yaitu Tuan $\mathrm{M}$ akan memperoleh haknya sesuai dengan hak Tuan $\mathrm{P} \&$ Tuan $\mathrm{Q}$ yang dibelinya ataukah diadakan perjanjian baru. Apabila menggunakan asumsi bahwa Tuan $M$ akan memperoleh hak atas laba rugi firma sesuai dengan proporsi hak Tuan $P$ \& $Q$ yang dibelinya, maka tidak terjadi masalah. Misalnya saja perbandingan laba rugi firma sebelum \& sesudah masuknya Tuan M sbb:

\begin{tabular}{|l|l|l|}
\hline Nama & Hak atas Laba Sebelum Masuknya & $\underline{\text { Hak atas Laba Setelah Masuknya }}$ \\
Anggota & Tuan M & $\underline{\text { Tuan M }}$ \\
Tuan P & $28 \%$ & $21 \%$ \\
Tuan Q & $40 \%$ & $10 \%$ \\
Tuan S & $32 \%$ & $32 \%$ \\
Tuan M & -- & $37 \% *)$ \\
Jumlah & $100 \%$ & $100 \%$ \\
\hline
\end{tabular}

*) Hak Tuan M dihitung sbb :

$(1 / 4 \times 28 \%)+(3 / 4 \times 40 \%)=37 \%$

Anggota baru dapat menjadi anggota firma dengan cara menyetorkan kekayaannya atau memasukkan investasi tersebut ke dalam firma. Dengan memasukkan investasi tersebut, anggota lama akan mengakui hak \& kewajiban anggota baru \& selanjutnya anggota baru tersebut menjadi pemilik firma bersama-sama anggota-anggota lama.

Ada beberapa beberapa kemungkinan pencatatan besarnya modal anggota baru yang diakui oleh firma, sbb:

a. Modal Angqota Baru Dicatat Sebesar Setoran Kekayaannya

Misalnya, sebuah firma struktur modalnya terdiri dari:

Modal Tn. Dana = Rp 5.000.000 (30\%) 
Modal Tn. Dino = Rp 3.500.000 (20\%)

Modal Tn. Dono = Rp 6.500.000 (50\%)

Tuan Danar masuk menjadi anggota firma dengan menyetorkan uang sebesar Rp 4.000.000 \& diakui haknya sebesar setorannya. Maka jurnal yang dibuat atas masuknya Tuan Danar sbb:

Kas

Rp 4.000.000

Modal Tuan Danar $\quad$ Rp 4.000.000

Akibat masuknya Tuan Danar, maka struktur permodalan firma menjadi:

\begin{tabular}{lccc} 
Modal Tuan Dana & $=\operatorname{Rp}$ & 5.000 .000 & $(30 \%)$ \\
Modal Tuan Dino & $=\operatorname{Rp}$ & 3.500 .000 & $(20 \%)$ \\
Modal Tuan Dono & $=\operatorname{Rp}$ & 6.500 .000 & $(50 \%)$ \\
Modal Tuan Danar & $=\operatorname{Rp}$ & 4.000 .000 & $?$ \\
Jumlah & \multicolumn{3}{c}{$=\operatorname{Rp} 19.000 .000$} \\
$100 \%$ & &
\end{tabular}

Permasalahn yang timbul adalah berapa hak atas laba rugi firma milik Tuan Danar???

Masalah pembagian laba-rugi harus dibuat perjanjian lagi oleh anggota-anggota firma tersebut. Misal, Tuan Danar diberi hak atas laba firma sebesar $25 \%$ maka hak atas laba untuk anggota lama tinggal $75 \%$ \& ini akan dibagi kepada Tuan Dana, Tuan Dino \& Tuan Dono dengan cara sbb:

\begin{tabular}{|l|l|c|}
\hline \multirow{2}{*}{ Nama Anggota } & \multicolumn{2}{|c|}{ Hak atas Laba Rugi } \\
\cline { 2 - 3 } & Sebelum masuknya Tn. Danar & Sesudah masuknya Tn. Danar \\
\hline Tuan Dana & $30 \%$ & $30 \% \times 75 \%=22,50 \%$ \\
\hline Tuan Dino & $20 \%$ & $20 \% \times 75 \%=15 \%$ \\
\hline Tuan Dono & $50 \%$ & $50 \% \times 75 \%=37,50 \%$ \\
\hline Tuan Danar & - & $=25 \%$ \\
\hline
\end{tabular}




\begin{tabular}{|l|l|c|}
\hline Jumlah & $100 \%$ & $100 \%$ \\
\hline
\end{tabular}

\section{b. Modal Anggota baru Dicatat Lebih Besar Daripada Setorannya}

Dengan menggunakan contoh pada no.1 di atas, Tuan Danar masuk dengan meyetorkan uang sebesar Rp 4.000.000 \& diakui haknya sebesar $30 \%$ dari total modal firma yang baru, maka modal Tuan Danar yang dicatat oleh Firma akan dihitung dengan cara sbb:

1. Jumlah modal Firma yang baru adalah $=$

$R p 5.000 .000+R p 3.500 .000+R p 6.500 .000+R p 4.000 .000=R p$ 19.000.000

2. Hak modal Tuan Danar yang diakui Firma sbb:

30\% x Rp 19.000.000

Setoran uang Tn. Danar

Kelebihan modal di atas setoran

$$
\begin{aligned}
& =\operatorname{Rp~} 5.700 .000 \\
& =(\operatorname{Rp~} 4.000 .000) \\
& =\operatorname{Rp~} 1.700 .000
\end{aligned}
$$

Berdasarkan perhitungan di atas, ternyata modal Tn. Danar dicatat lebih tinggi daripada setorannya. Kelebihan pencatatan modal di atas setorannya dapat diperlakukan menjadi dua jenis perlakuan, yaitu:

1. Kelebihan tersebut dianggap sebagai bonus yang diberikan kepada anggota baru

Apabila kelebiham modal Tn. Danar di atas setorannya sebesar Rp 1.700.000 itu dianggap sebagai bonus yang diterimanya dari anggota lama, maka modal anggota lama akan berkurang Rp 1.700.000 \& ditanggung oleh masing-masing anggota lama sesuai dengan perbandingan Laba-Rugi dengan perhitungan sbb:

$\begin{array}{rrrr}\text { Tn. Dana } & =30 \% \times \operatorname{Rp~} 1.700 .000 & =R p & 510.000 \\ \text { Tn. Dino } & =20 \% \times \operatorname{Rp~} 1.700 .000 & =R p & 340.000 \\ \text { Tn. Dono } & =50 \% \times \operatorname{Rp~} 1.700 .000 & =R p & 850.000 \\ \text { Jumlah } & =R p 1.700 .000\end{array}$ 
Jurnal yang dibuat untuk mencatat masuknya Tuan Danar adalah:

Kas

Modal Tn. Dana

Modal Tn. Dino

Modal Tn. Dono

Modal Tn. Danar
Rp 4.000.000

510.000

340.000

850.000

Dengan adanya bonus untuk Tn. Danar, maka komposisi modal Firma beserta perbandingan Laba-Rugi sbb:

\begin{tabular}{|c|c|c|c|c|}
\hline \multirow{2}{*}{$\begin{array}{c}\text { Nama } \\
\text { Anggota }\end{array}$} & \multicolumn{2}{|c|}{ Jumlah Modal } & \multicolumn{2}{|c|}{ Hak atas Laba-Rugi Firma } \\
\hline & $\begin{array}{l}\text { Sebelum Tn. } \\
\text { Danar Masuk }\end{array}$ & $\begin{array}{l}\text { Sesudah Tn. } \\
\text { Danar Masuk }\end{array}$ & $\begin{array}{l}\text { Sebelum Tn. } \\
\text { Danar Masuk }\end{array}$ & $\begin{array}{l}\text { Sesudah Tn. Danar } \\
\text { Masuk }\end{array}$ \\
\hline Tuan Dana & $\begin{array}{ll}\mathrm{Rp} & 5.000 .000\end{array}$ & Rp 4.490 .000 & $30 \%$ & $\begin{array}{l}30 \% \times 70 \%= \\
21 \%\end{array}$ \\
\hline Tuan Dino & $\mathrm{Rp} \quad 3.500 .000$ & Rp 3.160 .000 & $20 \%$ & $\begin{array}{l}20 \% \times 70 \%= \\
14 \%\end{array}$ \\
\hline Tuan Dono & $\mathrm{Rp} \quad 6.500 .000$ & $\mathrm{Rp} 5.650 .000$ & $50 \%$ & $\begin{array}{l}50 \% \times 70 \%= \\
35 \%\end{array}$ \\
\hline Tuan Danar & - & $\mathrm{Rp} 5.700 .000$ & - & $30 \%$ \\
\hline Jumlah & Rp 15.000.000 & Rp 19.000.000 & $100 \%$ & $100 \%$ \\
\hline
\end{tabular}

. Pembentukan Goodwill untuk Anggota Baru Apabila kelebihan kelebihan modal Tn. Danar di ats setorannya sebesar Rp 1.700.000 dianggap sebagai pembentukan Goodwill untuk Firma, maka Goodwill akan dicatat sebesar Rp 1.700.000 sedangkan modal anggota-anggota lama tidak berubah sehingga jurnal yang harus dibuat untuk mencatat pembentukan Goodwill \& masuknya Tn. Danar sbb:

Kas Rp 4.000.000

Goodwill Rp 1.700 .000

Modal Tn. Danar

Rp 5.700.000 
Modal anggota lama tidak dikurangi jumlahnya, oleh karena itulah dibentuk Goodwill. Dengan adanya pembentukan Goodwill tsb, komposisi modal masing-masing adalah sbb:

\begin{tabular}{|l|l|l|l|l|}
\hline Nama Anggota & \multicolumn{2}{|c|}{ Jumlah Modal } & \multicolumn{2}{c|}{ Hak atas Laba-Rugi Firma } \\
\hline & $\begin{array}{l}\text { Sebelum Tn. } \\
\text { Danar Masuk }\end{array}$ & $\begin{array}{l}\text { Sesudah Tn. } \\
\text { Danar Masuk }\end{array}$ & $\begin{array}{l}\text { Sebelum Tn. } \\
\text { Danar Masuk }\end{array}$ & $\begin{array}{l}\text { Sesudah Tn. Danar } \\
\text { Masuk }\end{array}$ \\
\hline Tuan Dana & Rp 5.000.000 & Rp 5.000.000 & $30 \%$ & $30 \%$ X 70\%=21\% \\
\hline Tuan Dino & Rp 3.500.000 & Rp 3.500.000 & $20 \%$ & $20 \%$ X 70\% = 14\% \\
\hline Tuan Dono & Rp 6.500.000 & Rp 6.500.000 & $50 \%$ & $50 \%$ X 70\% $=35 \%$ \\
\hline Tuan Danar & - & Rp 5.700.000 & - & $30 \%$ \\
\hline Jumlah & Rp 15.000.000 & Rp 20.700.000 & $100 \%$ & $100 \%$ \\
\hline
\end{tabular}

\section{c. Modal Angqota Baru Dicatat Lebih Kecil Daripada Setorannya}

Misalnya sebuah Firma mempunyai komposisi sbb:

\begin{tabular}{|l|l|l|}
\hline Nama Anggota & Jumlah Modal & Hak atas Laba-Rugi \\
\hline Tuan Aries & Rp 10.500 .000 & $40 \%$ \\
\hline Ny. Nita & Rp 12.000 .000 & $60 \%$ \\
\hline Jumlah & Rp 22.500.000 & $100 \%$ \\
\hline
\end{tabular}

Untuk memperluas usahanya, Tn. Aries \& Ny. Nita setuju untuk mengajak Tn. Rifani sebagai anggota Firma yang baru. Untuk itu Tn. Rifani diharuskan membayar uang tunai sebesar Rp 7.500.000 $\&$ untuk itu haknya diakui sebesar $23 \%$ dari modal yang baru. Langkah pertama yang harus dilakukan adalah menghitung dahulu berapakah jumlah modal Tn. Rifani yang dicatat dalam Firma sbb: Jumlah modal Firma yang baru adalah Rp 30.000.000 yang terdiri dari : Rp 10.500.000 + Rp 12.000.000 + Rp 7.500.000

Hak modal Tn. Rifani $=23 \% \times$ Rp 30.000.000 $=$ Rp 6.900.000 
Setoran Tn. Rifani

Kelebihan setoran di atas modal
$=\mathrm{Rp} 7.500 .000$

$=\operatorname{Rp} \quad 600.000$

Dengan adanya perhitungan tsb, hak modal Tn. Rifani dicatat lebih kecil daripada setorannya sebesar Rp 600.000. Kekurangan pencatatan modal dari setorannya itu dianggap sebagai pemberian bonus dari anggota baru kepada anggota lama atau pembentukan bonus untuk anggota lama.

Apabila modal Tn. Rifani (anggota baru) dicatat lebih kecil daripada setorannya sebesar Rp 600.000 tsb dianggap sebagai pemberian bonus kepada anggota lama, maka akibatnya modal anggota lama akan bertambah masing-masing sebesar:

- Tn. Aries $=40 \% \times$ Rp 600.000

$=\operatorname{Rp} 240.000$

- Ny. Nita $=60 \%$ X Rp 600.000

$\equiv \operatorname{Rp} 360.000$

Jumlah $=$ Rp 600.000

Jurnal yang harus dibuat untuk mencatat pemberian bonus kepada anggota lama \& masuknya Tn. Rifani sbb:

Kas

Rp 7.500.000

Modal Tn. Rifani

Rp 6.900.000

Modal Tn. Aries

240.000

Modal Ny. Nita

360.000

Dengan masuknya Tn. Rifani, komposisi modal \& hak atas Laba Rugi masing-masing anggota sbb:

\begin{tabular}{|l|l|l|l|l|}
\hline $\begin{array}{l}\text { Nama } \\
\text { Anggota }\end{array}$ & \multicolumn{2}{|l|}{ Jumlah Modal } & \multicolumn{2}{l|}{ Hak atas Laba-Rugi Firma } \\
\hline & $\begin{array}{l}\text { Sebelum Tn. } \\
\text { Rifani Masuk }\end{array}$ & $\begin{array}{l}\text { Sesudah Tn. } \\
\text { Rifani Masuk }\end{array}$ & $\begin{array}{l}\text { Sebelum Tn. } \\
\text { Rifani } \\
\text { Masuk }\end{array}$ & $\begin{array}{l}\text { Sesudah Tn. Rifani } \\
\text { Masuk }\end{array}$ \\
\hline Tuan Aries & $\mathrm{Rp} 10.500 .000$ & $\mathrm{Rp} 10.740 .000$ & $40 \%$ & $40 \%$ X 77\%=30,8\% \\
\hline Nyonya Nita & $\mathrm{Rp} 12.000 .000$ & $\mathrm{Rp} 12.360 .000$ & $60 \%$ & $60 \%$ X7\% $=46,2 \%$ \\
\hline Tuan Rifani & - & $\mathrm{Rp} 6.900 .000$ & & $23,0 \%$ \\
\hline
\end{tabular}




\begin{tabular}{|l|l|l|l|l|}
\hline Jumlah & $\operatorname{Rp~} 22.500 .000$ & $\operatorname{Rp} 30.000 .000$ & $100 \%$ & $100 \%$ \\
\hline
\end{tabular}

\section{d. Modal Anggota Baru Dicatat Setelah Pembentukan Goodwill untuk Anggota Lama}

Dengan menggunakan contoh Firma Tn. Aries \& Ny. Nita di atas apabila setoran Tn. Rifani sebesar Rp 7.500.000 tsb dianggap sebagai $23 \%$ dari total modal, maka total modal persekutuan yang baru adalah sbb:

100/23 X Rp 7.500.000 $=\operatorname{Rp} 32.608 .700$ (pembulatan)

Modal Firma yang

sesungguhnya

$=\underline{R p 30.000 .000}$

Goodwill yang harus dibentuk $=R p \quad 2.608 .700$

Selanjutnya Goodwill sebesar Rp 2.608.700 tsb dibagi kepada anggota lama dengan perhitungan sbb:

-Tn. Aries $=40 \% \times$ Rp 2.608.700

- Ny. Nita $=60 \%$ X Rp 2.608.700

Jumlah

$$
=\operatorname{Rp~2.608.700}
$$

Jurnal yang harus dibuat ada 2 macam, yaitu:

1) Jurnal untuk mencatat pembentukan Goodwill:

Goodwill

Rp 2.608.700

Modal Tn. Aries

Rp 1.043 .480

Modal Ny. Nita

Rp 1.565.220

2) Jurnal untuk mencatat masuknya Tn. Rifani:

Kas

Rp 7.500.000

Modal Tn. Rifani

Rp 7.500.000

Dengan adanya pembentukan Goodwill untuk anggota lama \& masuknya Tn. Rifani sebagai anggota baru, komposisi modal Firma sbb:

Nama Anggota
Jumlah Modal

Hak atas Laba-Rugi Firma 


\begin{tabular}{|l|l|l|l|l|}
\hline & $\begin{array}{l}\text { Sebelum Tn. } \\
\text { Rifani Masuk }\end{array}$ & $\begin{array}{l}\text { Sesudah Tn. } \\
\text { Rifani Masuk }\end{array}$ & $\begin{array}{l}\text { Sebelum Tn. } \\
\text { Rifani Masuk }\end{array}$ & $\begin{array}{l}\text { Sesudah Tn. Rifani } \\
\text { Masuk }\end{array}$ \\
\hline $\begin{array}{l}\text { Tuan } \\
\text { Aries }\end{array}$ & $\begin{array}{l}\text { Rp } \\
10.500 .000\end{array}$ & Rp 11.543.480 & $40 \%$ & $40 \% \times 77 \%=30,8 \%$ \\
\hline $\begin{array}{l}\text { Nyonya } \\
\text { Nita }\end{array}$ & $\begin{array}{l}\text { Rp } \\
12.000 .000\end{array}$ & Rp 13.565.220 & $60 \%$ & $60 \% \times 77 \%=46,2 \%$ \\
\hline $\begin{array}{l}\text { Tuan } \\
\text { Rifani }\end{array}$ & - & Rp 7.500.000 & & $=23,0 \%$ \\
\hline Jumlah & Rp 22.500.000 & Rp 32.608.700 & $100 \%$ & $100 \%$ \\
\hline
\end{tabular}

B. Perubahan Pemilikan Firma Akibat Adanya Anggota Baru yang Keluar

Apabila ada salah satu atau lebih anggota Firma keluar dari keanggotaan Firma, maka anggota tersebut akan menyelesaikan masalah keuangan atau kekayaannya yang masih tertanam di dalam Firma. Demikian pula halnya apabila ada anggota yang meninggal dunia.

Pada umumnya anggota yang keluar akan memperoleh hak kekayaannya sebesar yang tercatat di dalam modal Firma. Ada beberapa kemungkinan yang dapat dilakukan untuk menyelesaikan masalah keuangan anggota yang keluar atau meninggal dunia. Kemungkinan-kemungkinan tsb adalah:

a. Anggota Firma yang keluar memperoleh hak sebesar saldo modalnya

b. Anggota Firma yang keluar memperoleh hak lebih besar daripada saldo modalnya

c. Anggota Firma yang keluar memperoleh hak lebih kecil daripada saldo modalnya 
1. Anggota Firma yang Keluar \& akan memperoleh haknya sebesar saldo modalnya, maka terlebih dahulu harus dihitung saldo modal akhir anggota tsb setelah disesuaikan dengan laba atau rugi sampai dengan saat anggota tsb keluar. Yang dimaksud dengan saldo modal disini adalah saldo modal akhir.

Contoh:

Firma KLMN membagi laba - rugi kepada anggotanya setelah dikurangi dengan perbandingan 3:4:1:2. Pada tgl 1 Agustus 20XY 20XY, para anggota telah menyetujui Tn. M keluar dari keanggotaan Firma. Pada saat itu struktur modal Firma \& tarif gaji bulanan sbb:

\begin{tabular}{|l|l|l|}
\hline $\begin{array}{l}\text { Nama } \\
\text { Anggota }\end{array}$ & $\begin{array}{l}\text { Jumlah Modal } \\
\text { Per 1 Januari } \\
\text { 20XY }\end{array}$ & $\begin{array}{l}\text { Gaji } \\
\text { Bulanan }\end{array}$ \\
\hline Tuan K & Rp 6.000 .000 & Rp 200.000 \\
\hline Tuan L & Rp 7.500.000 & Rp 350.000 \\
\hline Tuan M & Rp 3.400.000 & Rp 275.000 \\
\hline Tuan N & Rp 5.800 .000 & Rp 300.000 \\
\hline Jumlah & Rp 22.700.000 & \\
\hline
\end{tabular}

Diketahui pula bahwa laba Firma sampai dengan tgl 1 Agustus 20XY adalah sebesar Rp 22.875.000.

Berdasarkan contoh diatas, terlebih dahulu harus dihitung saldo modal akhir masing-masing anggota sbb:

\begin{tabular}{|l|l|l|l|l|l|}
\hline KETERANGAN & $\begin{array}{l}\text { TUAN K } \\
(\mathrm{Rp})\end{array}$ & $\begin{array}{l}\text { TUAN L } \\
(\mathrm{Rp})\end{array}$ & $\begin{array}{l}\text { TUAN M } \\
(\mathrm{Rp})\end{array}$ & $\begin{array}{l}\text { TUAN N } \\
(\mathrm{Rp})\end{array}$ & $\begin{array}{l}\text { JUMLAH } \\
(\mathrm{Rp})\end{array}$ \\
\hline
\end{tabular}




\begin{tabular}{|c|c|c|c|c|c|}
\hline $\begin{array}{l}\text { 1. Gaji } \\
1 / 1-1 / 820 X Y \\
(7 \text { Bulan) }\end{array}$ & 1.400 .000 & 2.450 .000 & 1.925 .000 & 2.100 .000 & 7.875 .000 \\
\hline 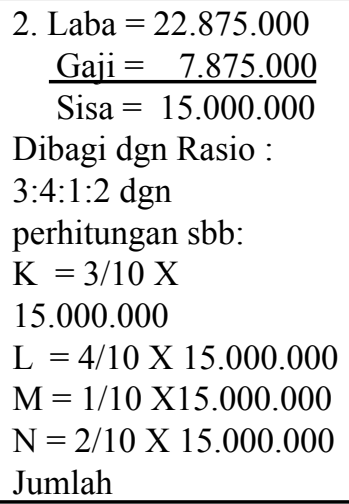 & 4.500 .000 & 6.000 .000 & 1.500 .000 & 3.000 .000 & 15.000 .000 \\
\hline $\begin{array}{l}\text { 3. Saldo Modal Awal } \\
\text { Per } 1 \text { Januari 20XY }\end{array}$ & 6.000 .000 & 7.500 .000 & 3.400 .000 & 5.800 .000 & 22.700 .000 \\
\hline $\begin{array}{l}\text { Saldo Modal Akhir Per } \\
1 \text { Agustus 20XY }\end{array}$ & 11.900 .000 & 15.950 .000 & 6.825 .000 & 10.900 .000 & 45.575 .000 \\
\hline
\end{tabular}

Berdasarkan perhitungan di atas, jurnal yang harus dibuat untuk mencatat pengakuan hak Tn. M pada saat keluar:

$$
\begin{array}{cc}
\text { Modal Tn. M Rp 6.825.000 } \\
\text { Hutang pada Tn. M } \quad \text { Rp 6.825.000 }
\end{array}
$$

Apabila keluarnya Tn. M langsung dilunasi/ dibayar oleh Firma:

Modal Tn. M

Rp 6.825.000

Kas

Rp 6.825.000

\begin{tabular}{|c|c|c|}
\hline $\begin{array}{l}\text { NAMA } \\
\text { ANGGOT } \\
\text { A }\end{array}$ & $\begin{array}{l}\text { SEBELUM } \\
\text { TUAN M } \\
\text { KELUAR }\end{array}$ & $\begin{array}{l}\text { SESUDAH } \\
\text { TUAN M } \\
\text { KELUAR }\end{array}$ \\
\hline TUAN K & $\begin{array}{ll}\mathrm{RP} & 11.900 .000\end{array}$ & $\begin{array}{ll}\text { RP } & 11.900 .000\end{array}$ \\
\hline TUAN L & RP 15.950 .000 & RP 15.950 .000 \\
\hline TUAN M & $\begin{array}{ll}\mathrm{RP} & 6.825 .000 \\
\end{array}$ & - \\
\hline TUAN N & $\begin{array}{ll}\text { RP } & 10.900 .000 \\
\end{array}$ & RP 10.900 .000 \\
\hline JUMLAH & $\begin{array}{ll}\mathrm{RP} & 45.575 .000\end{array}$ & RP 38.750 .000 \\
\hline
\end{tabular}

Dengan keluarnya Tn. M komposisi modal Firma tampak sbb: 


\section{Anggota Firma yang Keluar Memperoleh Hak Lebih Besar}

Daripada Saldo Modal akhirnya, maka ada 2 kemungkinan perlakuan akuntansi yang timbul;, yaitu:

1. Kelebihan pembayaran di atas saldo modalnya tsb dianggap sebagai pemberian bonus kepada anggota yang keluar. Dengan menggunakan contoh Firma KLMN di atas, misalnya saja hak Tuan $\mathrm{M}$ yang keluar disetujui oleh anggota yang lain sebesar Rp 7.725.000, maka kelebihan pembayarannya adalah:

Hak Tuan M yang diakui

Saldo modal akhir Tuan M

Bonus untuk Tuan M

$$
\begin{aligned}
& =\operatorname{Rp} 7.725 .000 \\
& =\operatorname{Rp} 6.825 .000 \\
& =\operatorname{Rp} \quad 900.000
\end{aligned}
$$

Bonus sebesar Rp 900.000 ini akan ditanggung oleh anggota-anggota yang tinggal dengan rasio 3:4:2 dengan perhitungan sbb:

Tn. $\mathrm{K}=3 / 9 \times \operatorname{Rp} 900.000=\operatorname{Rp} 300.000$

Tn. $L=4 / 9 \times R p 900.000=\operatorname{Rp} 400.000$

Tn. $N=2 / 9 \times \operatorname{Rp} 900.000 \quad \equiv \operatorname{Rp} 200.000$ Jumlah $=\operatorname{Rp} 900.000$

Jurnal untuk mencatat keluarnya Tn. M adalah:

Modal Tn. K Rp 300.000

Modal Tn. L Rp 400.000

Modal Tn. M Rp 6.825.000

Modal Tn. N Rp 200.000 hutang pada Tn. M/Kas

2) Kelebihan pembayaran di atas saldo modalnya dianggap sebagai pembentukan Goodwill sebab anggota-anggota yang tinggal tidak mau saldonya dikurangi. Dengan menggunakan contoh di atas, kelebihan pembayaran kepada Tn. M sebesar Rp 900.000 
dianggap sebagai pembentukan Goodwill yang dapat dibagi menjadi:

\section{a. Pembentukan Goodwill hanya untuk anggota yang keluar, jurnal yang harus dibuat adalah:}

Modal Tn. M

Rp 6.825.000

Goodwill

900.000

Hutang pada Tn. M/Kas

Rp 7.725.000

b. Pembentukan Goodwill untuk seluruh anggota Firma.

Dalam hal ini, kelebihan Rp 900.000 yang dibayarkan kepada anggota yang keluar adalah merupakan $10 \%$ dari keseluruhan Goodwill (sebab perbandingan laba rugi 3:4:2:1). Total Goodwill yang dibentuk :

10/1 X Rp $900.000=\operatorname{Rp} 9.000 .000$

Goodwill sebesar Rp 9.000.000 tsb akan dibagi

kepada para anggota sbb:

- $\quad$ Tn. $\mathrm{K}=3 / 10 \times \operatorname{Rp} 9.000 .000=\operatorname{Rp} 2.700 .000$

- $\mathrm{Tn} . \mathrm{L}=4 / 10 \times \operatorname{Rp} 9.000 .000=\operatorname{Rp} 3.600 .000$

- $\operatorname{Tn} . \mathrm{M}=1 / 10 \times \operatorname{Rp} 9.000 .000=\mathrm{Rp} 900.000$

- $\quad$ Tn. $\mathrm{N}=2 / 10 \times \operatorname{Rp} 9.000 .000=\operatorname{Rp} 1.800 .000$

$$
\text { Jumlah }=\operatorname{Rp} 9.000 .000
$$

Jurnal pembentukan Goodwill untuk seluruh anggota adalah sbb:

Goodwill Rp 9.000.000

Modal Tn. K

Rp 2.700.000

Modal Tn. L

Rp 3.600.000

Modal Tn. M

Rp 900.000

Modal Tn. N

Rp 1.800.000

Jurnal untuk mencatat keluarnya Tn. M adalah:

Modal Tn. M

Rp 7.725.000

Hutang pada Tn. M atau Kas

Rp 7.725.000 


\section{Anggota Firma Yang Keluar memperoleh Hak Lebih Kecil Daripada Saldo Modalnya}

Apabila anggota yang keluar haknya diberikan lebih kecil daripada saldo modal akhirnya, maka ada 2 perlakuan akuntansi, yaitu:

1. Selisih antara hak \& saldo modal akhirnya dianggap sebagai pemberian bonus kepada anggota yang ditinggalkan.

2. Selisih antara hak \& saldo modal akhirnya dianggap sebagai pembentukan Goodwill.

Dengan menggunakan contoh sebelumnya, misalnya saja Tn. M yang keluar bersedia dibayar atau dinilai hak modalnya sebesar Rp 6.195.000 sedangkan saldo modal akhirnya sebesar Rp 6.825.000. akibatnya selisih antara hak \& saldo modal akhir Tn. M adalah sebesar:

$R p 6.825 .000-R p 6.195 .000=R p 630.000$

1. Dengan anggapan selisih $\mathrm{Rp} 630.000$ tsb dianggap sebagai pemberian bonus untuk anggota yang tinggal, maka jurnalnya:

Modal Tn. M

Rp 6.825.000

Modal Tn. K

Rp 210.000

Modal Tn. L

Rp 280.000

Modal Tn. N

Rp 140.000

Hutang pada Tn. M/Kas

Rp 6.195.000

Perhitungan pembagian bonus:

Tn. $\mathrm{K}=3 / 9 \times \mathrm{Rp} 630.000$

$=\operatorname{Rp} 210.000$

Tn. $\mathrm{L}=4 / 9 \times \mathrm{Rp} 630.000$

$=\operatorname{Rp} 280.000$

Tn. $N=2 / 9 \times \operatorname{Rp} 630.000$

$=\operatorname{Rp} 140.000$

$$
\text { Jumlah }=\operatorname{Rp} 630.000
$$

Jurnal yang harus dibuat untuk mencatat keluarnya Tn. M adalah:

Modal Tn. M Rp 6.825.000 
Bonus

Rp $\quad 630.000$

Hutang Tn. M/Kas

Rp 6.195.000

2. Selisih antara hak \& saldo modal akhirnya dianggap sebagai pembentukan Goodwill

Catatan: Goodwill negatif artinya adanya pengurangan terhadap Goodwill Firma yang sudah terbentuk sebelumnya. Jadi metode pembentukan Goodwill pada anggota Firma yang keluar haknya dicatat lebih kecil daripada setorannya hanya dapat digunakan/dilakukan apabila sudah ada Goodwill yang sudah terbentuk sebelumnya pada buku Firma.

Metode goodwill bisa digunakan dalam kasus perubahan pemilikan firma, tetapi bila terjadi goodwill negatif, maka metode tsb tidak boleh digunakan kecuali sebelumnya firma sudah memiliki goodwill yang bersaldo positif.

\section{BAB 5}

\section{Akuntansi Pembubaran Firma}

\section{Capaian Pembelajaran (CP):}

a. Mahasiswa dapat memahami latar belakang suatu firma dibubarkan dan tahap-tahap dalam akuntansi pembubaran firma

b. Mahasiswa dapat memahami prosedur akuntansi pembubaran firma dengan menggunakan metode likuidasi dilakukan secara serentak beserta perhitungan dan pencatatannya

c. Mahasisw dapat memahami prosedur akuntansi pembubaran firma dengan menggunakan metode likuidasi dilakukan secara berangsur atau bertahap beserta perhitungan dan pencatatannya, baik tanpa menggunakan program kas maupun dengan menggunakan program kas 
Pembubaran Firma dapat diakibatkan oleh adanya kebangkrutan dalam usaha atau hal-hal lain yang akhirnya menjadi likuidasi Firma.

Definisi bangkrut adalah suatu keadaan perusahaan yang mengalami kekurangan \& ketidakcukupan dana untuk menjalankan atau melanjutkan usahanya. Sebagai akibat dari adanya kebangkrutan ini adalah berupa penutupan usaha \& pada akhirnya terjadi pembubaran usaha atau likuidasi. Jadi istilah bangkrut disini lebih menekankan pada aspek ekonomis perusahaan yaitu berupa kegagalan perusahaan dalam mencapai tujuannya.

Sedangkan Likuidasi merupakan:

"suatu proses yang meliputi merubah aktiva non-kas menjadi kas, mengakui laba atau rugi dari proses perubahan aktiva non kas menjadi kas, melunasi kewajiban firma, \& akhirnya membagi semua kas yang dimiliki firma kepada masing-masing anggota sesuai dengan saldo modalnya."

Akuntansi Pembubaran Firma dalam bab ini akan membahas mengenai tahapan \& prosedur akuntansi untuk mencatat proses pembubaran Firma. Adapun tahapan dalam akuntansi pembubaran firma terdiri dari 2 tahapan, yaitu:

1. Tahap Realisasi, yaitu tahap pelaksanaan penjualan aktiva-aktiva non kas milik Firma menjadi kas (uang tunai), \&

2. Tahap Likuidasi, yaitu tahap pelunasan kewajiban-kewajiban atau hutang-hutang Firma \& diakhiri dengan pengembalian modal kepada para anggota Firma.

Kedua tahap tersebut adalah merupakan urutan dalam pembubaran Firma. Khusus untuk tahap yang kedua, yaitu tahap Likuidasi dapat menggunakan dua metode, yaitu:

1. Likuidasi yang dilakukan secara serentak (Lump Sum Liquidations), \& 
2. Likuidasi dilakukan secara berangsur atau bertahap (Installment Liquidations).

Untuk memperjelas pembahasan akuntansi pembubaran Firma dalam bab ini dapat dibuat skema pembahasan, yaitu sbb:

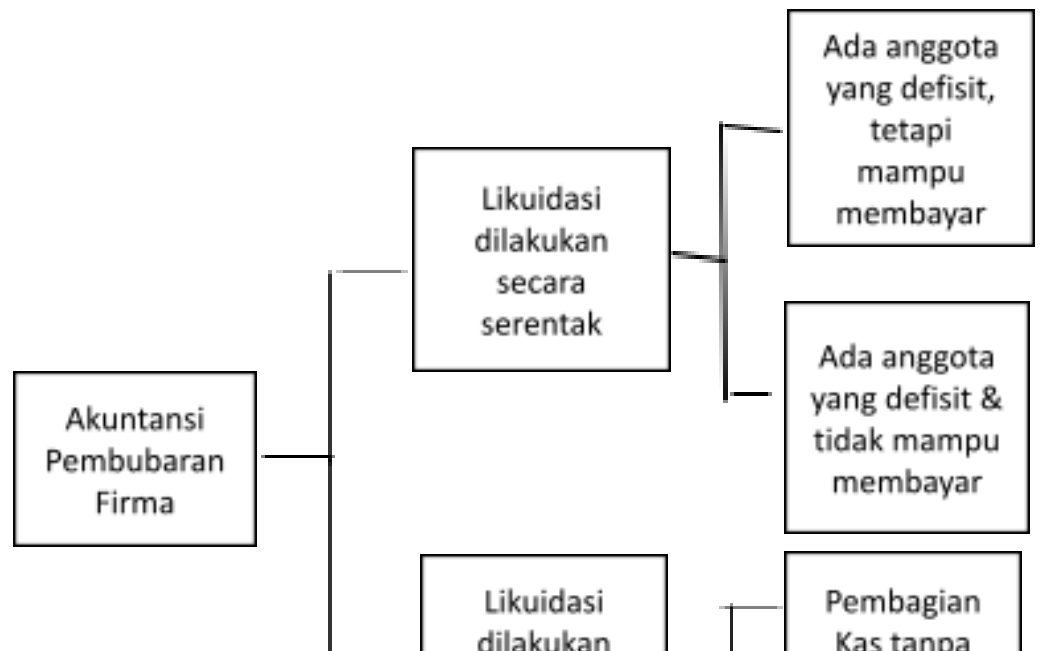


A. Akuntansi pembubaran persekutuan dengan Metode Likuidasi dilakukan secara serentak

Pembubaran Firma dengan likuidasi dilakukan secara serentak didahului dengan adanya penjualan semua aktiva non kas sampai seluruh aktiva non kas tersebut menjadi kas \& barulah dilakukan pembagian kas. Dengan kata lain, bila likuidasi dilakukan secara serentak, pertama-tama harus melalui tahap realisasi, kemudian setelah kasnya terkumpul barulah tahap likuidasi dilakukan.

Terdapat beberapa aturan dalam likuidasi ini, yaitu:

1. Pada saat realisasi aktiva non kas menjadi kas, apabila terjadi perbedaan antara nilai buku aktiva non kas dengan nilai realisasi (harga jual) yang dapat mengakibatkan laba atau rugi realisasi, maka laba atau rugi realisasi tersebut harus dibagikan kepada para anggota sesuai dengan perbandingan laba -rugi Firma. Laba rugi tersebut kemudian dicatat ke dalam saldo modal masing-masing anggota, kemudian saldo modal akhir para anggota akan digunakan sebagai dasar penyelesaian (likuidasi).

2. Setelah realisasi aktiva non kas menjadi kas \& semua uang tunai sudah terkumpul, maka urut-urutan pembagian kas diatur sbb: 
a. Menyelesaikan hutang-hutang firma kepada pihak luar

b. Menyelesaikan hutang-hutang firma kepada anggota firma

c. Melakukan pengembalian modal kepada para anggota

Contoh Soal:

akuntansi pembubaran firma dengan metode likuidasi dilakukan secara serentak

Firma "GHI"

NERACA

Per 31 Desember 20X1

\begin{tabular}{|lll|ll|}
\hline Kas & Rp & 10.000 .000 & Hutang Dagang & Rp 15.000 .000 \\
\hline Piutang Dagang & Rp 30.000 .000 & Hutang Bank & Rp 25.000.000 \\
\hline Persediaan & Rp 30.000 .000 & Hutang Tuan G & Rp 10.000 .000 \\
\hline Aktiva Tetap & Rp 40.000 .000 & Modal Tuan G & Rp 20.000.000 \\
\hline & & & Modal Tuan H & Rp 15.000 .000 \\
\hline & & Modal Tuan I & Rp 25.000.000 \\
\hline Jumlah Aktiva & Rp 110.000 .000 & Jumlah Hutang & \\
& & \& Modal & Rp 110.000.000 \\
\hline
\end{tabular}

Tuan G, Tuan H, \&Tuan I bersepakat membagi Laba -Rugi dengan perbandingan 30\%:20\%:50\%. Karena adanya ketidakcocokan, mereka 
bersepakat untuk melikuidasi Firmanya setelah tanggal 1 Januari 20X2. aktiva-aktiva non kas direalisasikan dengan rincian sbb:

- Persediaan berhasil dijual dengan harga Rp 38.000.000

- Aktiva tetap berhasil dijual dengan harga Rp 28.000.000

- Sedangkan piutang dagang dapat ditagih sebesar Rp 27.500.000

Membuat jurnal sesuai dengan urut-urutan likuidasi Firma yang meliputi jurnal realisasi \& jurnal likuidasi.

\begin{tabular}{|c|c|}
\hline KETERANGAN & JURNAL REALISASI \\
\hline 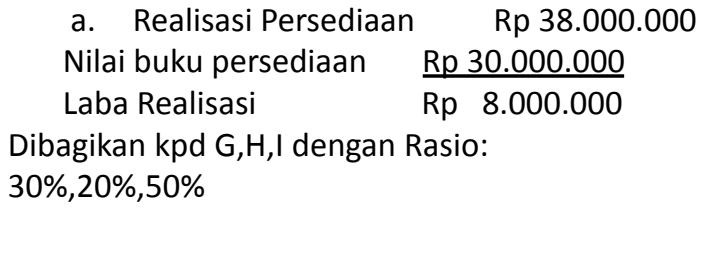 & \begin{tabular}{cr}
\multicolumn{2}{c}{ a. Jurnal Realisasi Persediaan: } \\
Kas & Rp 38.000 .000 \\
Persediaan & Rp 30.000 .000 \\
Modal G & Rp 2.400 .000 \\
Modal H & Rp 1.600 .000 \\
Modal I & Rp 4.000 .000
\end{tabular} \\
\hline 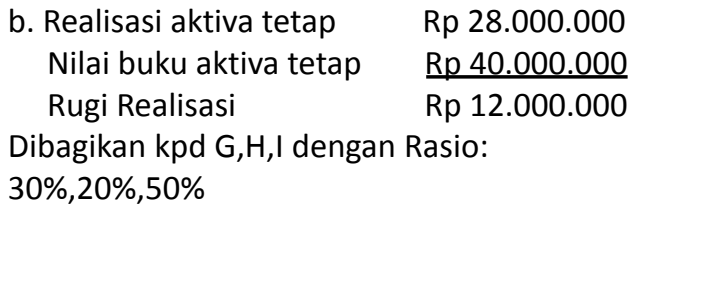 & $\begin{array}{ll}\text { b. Jurnal } & \text { Realisasi Aktiva Tetap: } \\
\text { Kas } & \text { Rp 28.000.000 } \\
\text { Modal G } & \text { Rp } 3.600 .000 \\
\text { Modal H } & \text { Rp } 2.400 .000 \\
\text { Modal I } & \text { Rp } 6.000 .000 \\
\quad \text { Aktiva Tetap } & R p \\
40.000 .000 & \end{array}$ \\
\hline $\begin{array}{l}\text { c. Realisasi Piutang Dagang } \operatorname{Rp} 27.500 .000 \\
\text { Nilai Buku Piutang Dagang } \frac{\mathrm{Rp} 30.000 .000}{\mathrm{Rp} 2.500 .000} \\
\text { Rugi realisasi } \\
\text { Dibagikan kpd G,H,I dengan Rasio: } \\
30 \%, 20 \%, 50 \%\end{array}$ & $\begin{array}{lll}\text { C. Jurnal Realisasi Piutang Dagang: } \\
\text { Kas } & \mathrm{Rp} & 27.500 .000 \\
\text { Modal G } & \mathrm{Rp} & 750.000 \\
\text { Modal H } & \mathrm{Rp} & 500.000 \\
\text { Modal I } & \mathrm{Rp} & 1.250 .000 \\
\quad \text { Piutang Dagang } & \mathrm{Rp} \\
30.000 .000 & \end{array}$ \\
\hline
\end{tabular}


Setelah Tahap Realisasi Aktiva non Kas selesai, dihitung dahulu jumlah uang tunai yang ada, yaitu: Rp 10.000 .000 (kas yang ada di Neraca)

$\underline{\text { Rp } 93.500 .000}$ (realisasi non kas)

Rp 103.500.000

Selanjutnya uang kas sebesar Rp 103.500.000 ini akan didistribusikan sesuai dengan tata urutan pembagian melalui tahap likuidasi dengan jurnal sbb:

\section{Likuidasi Kas}

\begin{tabular}{|c|c|}
\hline Keterangan & Jurnal Likuidasi \\
\hline $\begin{array}{l}\text { a. Menyelesaikan hutang kepada pihak luar } \\
\text { berupa hutang dagang Rp } 15.000 .000 \& \\
\text { hutang bank Rp } 25.000 .000\end{array}$ & $\begin{array}{l}\text { a. Menyelesaikan (melunasi) Hutang Dagang \& } \\
\quad \text { Bank: } \\
\text { Hutang Dagang } \ldots \ldots \ldots \ldots \ldots . \text { Rp } 15.000 .000 \\
\text { Hutang Bankj...............Rp } 25.000 .000 \\
\text { Kas...............................Rp } \\
40.000 .000\end{array}$ \\
\hline \begin{tabular}{lr} 
b. Uang kas yang ada & $\mathrm{Rp} 103.500 .000$ \\
Pelunasan hutang & $\mathrm{Rp} 40.000 .000$ \\
\cline { 2 - 2 } Sisa Kas & $\mathrm{Rp} 63.500 .000$ \\
Untuk membayar hutang Tuan G sebesar Rp \\
10.000.000 (kreditur intern)
\end{tabular} & $\begin{array}{l}\text { b. Menyelesaikan (melunasi) hutang pada Tuan G } \\
\text { Hutang Tuan G.............Rp } 10.000 .000 \\
\quad \text { Kas...........................Rp } \\
\text { 10.000.000 }\end{array}$ \\
\hline 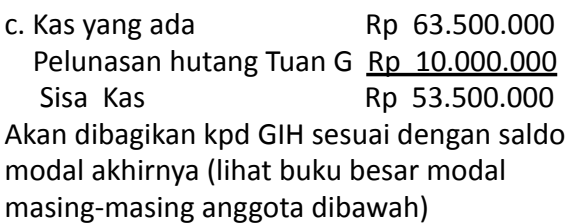 & 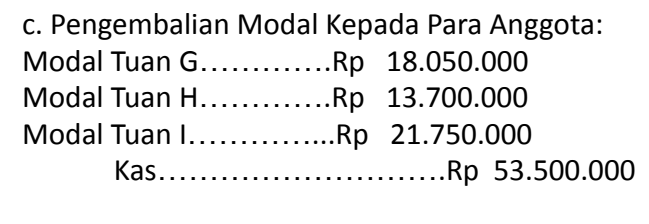 \\
\hline
\end{tabular}

Buku besar modal masing-masing anggota setelah adanya proses likuidasi firma sbb: 


\begin{tabular}{|l|l|l|l|l|}
\hline No & Keterangan & Debit (Rp) & Kredit (Rp) & Saldo (Rp) \\
\hline 1 & Saldo per 31 Des'20X1 & & 20.000 .000 & $\begin{array}{l}20.000 .00 \\
0\end{array}$ \\
\hline 2 & Realisasi Persediaan & & 2.400 .000 & $\begin{array}{l}22.400 .00 \\
0\end{array}$ \\
\hline 3 & Reaalisasi Aktiva Tetap & 3.600 .000 & & $\begin{array}{l}18.800 .00 \\
0\end{array}$ \\
\hline 4 & $\begin{array}{l}\text { Realisasi Piutang } \\
\text { Dagang }\end{array}$ & 750.000 & & \\
\hline & Saldo Akhir & & & 18.050 .00 \\
& & & & 0 \\
\hline
\end{tabular}

\begin{tabular}{|l|l|l|l|l|}
\hline No & Keterangan & Debit (Rp) & Kredit (Rp) & Saldo (Rp) \\
\hline 1 & Saldo per 31 Des'20X1 & & 15.000 .000 & 15.000 .000 \\
\hline 2 & Realisasi Persediaan & & 1.600 .000 & 16.600 .000 \\
\hline 3 & Reaalisasi Aktiva Tetap & 2.400 .000 & & 14.200 .000 \\
\hline 4 & $\begin{array}{l}\text { Realisasi Piutang } \\
\text { Dagang }\end{array}$ & 500.000 & & \\
\hline & Saldo Akhir & & & 13.700 .000 \\
\hline
\end{tabular}

Modal Tuan I

\begin{tabular}{|l|l|l|l|l|}
\hline No & Keterangan & Debit (Rp) & Kredit (Rp) & Saldo (Rp) \\
\hline 1 & Saldo per 31 Des'20X1 & & 25.000 .000 & 25.000 .000 \\
\hline 2 & Realisasi Persediaan & & 4.000 .000 & 29.000 .000 \\
\hline 3 & Reaalisasi Aktiva Tetap & 6.000 .000 & & 23.000 .000 \\
\hline
\end{tabular}




\begin{tabular}{|l|l|l|l|l|}
\hline 4 & $\begin{array}{l}\text { Realisasi Piutang } \\
\text { Dagang }\end{array}$ & 1.250 .000 & & \\
\hline & Saldo Akhir & & & 21.750 .000 \\
\hline
\end{tabular}

Setelah jurnal realisasi \& jurnal likuidasi dibuat, berarti proses pembubaran Firma sudah selesai dengan ditandai adanya pengembalian modal kepada masing-masing anggota sebesar saldo modal akhirnya.

Dalam pembubaran Firma dengan menggunakan metode likuidasi serentak, dapat timbul masalah dalam hal pengembalian modal kepada para anggotanya, yaitu:

a. Ada Anggota yang Saldo Modal Akhirnya Defisit, tetapi Mampu Membayar.

Dalam tahap realisasi aktiva non kas menjadi kas apabila terjadi kerugian dalam realisasinya, maka timbul kemungkinan adanya salah satu atau beberapa anggota yang modal akhirnya bersaldo debet atau defisit. Sebagai konsekuensinya, maka anggota yang modalnya defisit tsb diharuskan menghapuskan defisitnya dengan cara membayar/ menyetorkan sejumlah uang kepada firma sehingga saldo modalnya yang defisit akan habis/ dengan kata lain saldo modal akhirnya nol.

b. Ada Anggota yang Saldo Modal Akhirnya Defisit \& tidak Mampu Membayar.

Bagaimana jika terjadi anggota yang defisit tersebut tidak mampu membayar sejumlah uang untuk menghapuskan defisitnya???

Apabila terjadi demikian, maka yang menanggung defisit tersebut adalah anggota yang tidak defisit \& dibebankan sesuai dengan perbandingan Laba Rugi .

B. Pembubaran persekutuan dengan Metode Likuidasi dilakukan secara berangsur

Metode likuidasi secara berangsur adalah : 
"suatu metode pembayaran likuidasi dengan cara bertahap artinya setiap ada uang kas dari hasil realisasi aktiva non kas menjadi kas akan langsung dilakukan pembayaran kepada para anggota yang mempunyai saldo kredit rekening modalnya".

Ada dua metode pembagian kas yang dapat digunakan dalam likuidasi yang dilakukan secara berangsur, yaitu:

1. Pembagian kas tanpa program kas

2. Pembagian kas dengan program kas

a. Pembagian Kas Tanpa Program Kas

Yang dimaksud dengan pembagian kas tanpa program kas adalah perhitungan pembagian kas yang ada dari setiap tahap realisasi kepada para anggota setelah pelunasan hutang-hutang firma.

Adapun prosedur yang harus dilakukan dalam pembagian kas tanpa program kas sbb:

a. Mencatat realisasi aktiva non kas yang berhasil dijual

b. Membebankan laba/rugi akibat realisasi aktiva non kas kepada modal masing-masing anggota

c. Melunasi hutang-hutang dengan menggunakan uang kas yang ada

d. Apabila ada sebagian aktiva non kas yang belum berhasil dijual, maka dianggap suatu kerugian \& membebankan kerugian tersebut kepada para anggota

e. Apabila ada biaya likuidasi yang timbul, biaya tersebut dibebankan kepada para anggota sesuai dengan perbandinganpembagian laba rugi

f. Membagikan kas yang ada sebagai pengembalian modal kepada anggota-anggota yang mempunyai rekening modal bersaldo kredit (tidak defisit).

\section{CONTOH :}


- $\quad$ Sisa aktiva tetap laku dijual seharga Rp 390.000.000

Diminta:

Berdasarkan contoh kasus diatas, buatlah jurnal likuidasi Fa"PQRS"

beserta perhitungannya dengan menggunakan metode likuidasi berangsur!

Penyelesaian....

1. Likuidasi tahap 1 (bulan Januari 20X1)

a. Realisasi piutang Rp 15.000 .000

Realisasi aktiva tetap $\underline{\operatorname{Rp} 275.000 .000+}$ Jumlah kas hasil realisasi $\mathrm{Rp} 290.000 .000$

Laba realisasi aktiva tetap

Rp 275.000.000 - Rp 250.000.000 = Rp 25.000.000

Dibagikan kepada Tn. PQRS masing-massing sebesar:

Tn.P $=30 \% \times$ Rp 25.000.000 = Rp 7.500.000

Tn.Q $=20 \% \times$ Rp 25.000.000 = Rp 5.000.000

$\operatorname{Tn} . R=25 \% \times \operatorname{Rp} 25.000 .000=\operatorname{Rp} 6.250 .000$

$\operatorname{Tn} . S=25 \% \times \operatorname{Rp} 25.000 .000=\underline{R p ~ 6.250 .000+}$

Jumlah $=\operatorname{Rp} 25.000 .000$

Jurnal Realisasi Tahap 1 :

Kas

290.000.000

Piutang dagang

15.000 .000

Aktiva tetap 250.000 .000

Modal Tn. P

7.500 .000

Modal Tn. Q

5.000 .000

Modal Tn. R

6.250 .000

Modal Tn. S

6.250 .000

b. Selanjutnya diadakan pelunasan hutang-hutang Firma dgn jurnal sbb:

Hutang dagang $\quad 25.000 .000$

Hutang Tn. P $\quad 75.000 .000$ 
Hutang Tn.Q

Kas
50.000 .000

150.000.000

c. Membebankan aktiva non kas yang belum terjual dianggap sebagai kerugian dengan perhitungan sbb:

- Jumlah aktiva non kas yang ada Rp 920.000 .000

- $\quad$ Yang telah direalisasi Rp 265.000.000

Aktiva non kas yang belum terjual/ Rp 655.000.000 terealisasi

* Kerugian sebesar Rp 655.000.000 dibebankan kpd Tn. PQRS sesuai rasio yang telah ditentukan. Pembebanan rugi ini kana mengurangi saldo modalnya.

\begin{tabular}{|l|c|c|c|c|}
\hline & $\begin{array}{c}\text { Modal Tn.P } \\
\mathbf{( 3 0 \% )}\end{array}$ & $\begin{array}{c}\text { Modal Tn. Q } \\
(\mathbf{2 0 \%})\end{array}$ & $\begin{array}{c}\text { Modal Tn. R } \\
\mathbf{( 2 5 \% )}\end{array}$ & $\begin{array}{c}\text { Modal Tn. S } \\
(\mathbf{2 5 \% )}\end{array}$ \\
\hline Saldo 1 Jan 20X1 & 200.000 .000 & 175.000 .000 & 215.000 .000 & 260.000 .000 \\
\hline Laba Reali. Thp 1: & 7.500 .000 & 5.000 .000 & 6.250 .000 & 6.250 .000 \\
\hline & 207.500 .000 & 180.000 .000 & 221.250 .000 & 266.250 .000 \\
\hline $\begin{array}{l}\text { Rugi Aktiva non kas } \\
\text { yang belum dijual } \\
\text { Rp 655.000.000 }\end{array}$ & $(196.500 .000)$ & $(131.000 .000)$ & $(163.750 .000)$ & $(163.750 .000)$ \\
\hline Saldo 31 Jan 20X2 & 11.000 .000 & 49.000 .000 & 57.500 .000 & 102.500 .000 \\
\hline
\end{tabular}

d. Membagikan kas yang ada kepada anggota yang rekening modalnya bersaldo kredit sbb:

- Jumlah kas $\quad=$ Rp 80.000 .000

- Kas dari Realisasi $=\underline{290.000 .000}$

- Kas yang tersedia $=370.000 .000$ pada tahap 1

- Pelunasan hutang $=\underline{150.000 .000}$

Firma

Sisa kas yang dibagikan $=\mathrm{Rp} 220.000 .000$

Kepada anggota

Jurnal pembagian kas pada tahap $1 \mathrm{sbb}$ :

Modal Tn. P Rp 11.000.000

Modal Tn. Q

49.000 .000 
Modal Tn. R

Modal Tn. S

Kas
57.500 .000

102.500.000

Rp 220.000.000

Ket : untuk tahap II \& III sama penyelesaiannya sama dengan tahap I

2. Pembagian Kas dengan Program Kas

Dalam metode ini terlebih dahulu disusun rencana prioritas pembayaran kas sehingga para anggota sudah dapat menentukan siapa yang berhak menerima kas terlebih dahulu. Rencana prioritas pembayaran kas yang disusun sebelum proses pembubaran berlangsung sering disebut dengan istilah "Program Kas". Jadi program kas disusun dengan tujuan untuk menentukan prioritas atau tata urutan pembagian kas pada masing-masing anggota sehingga dapat diketahui siapa yang pertama kali menerima pembagian kas, kemudian siapa yang menempati urutan kedua \& seterusnya. Pembagian kas dengan program kas ini dilakukan setelah hutang atau kewajiban firma kepada kreditur ektern \& intern dilunasi. Prosedur akuntansi yang harus ditempuh untuk likuidasi berangsur dengan menggunakan program kas sbb:

a. Menghitung kemampuan untuk menanggung rugi maksimum masing-masing anggota firma.

b. Menyusun urutan prioritas pembayaran kas kepada para anggota

c. Membuat program pembayaran kas

d. Melaksanakan pembagian kas atau likuidasi sesuai dengan tata urutan yang berlaku \& program kas yang telah tersusun.

\section{Contoh Kasus}

Sebuah persekutuan yang didirikan oleh Tn. Andi, Ny. Ari, \& Nn. Afni telah bersepakat untuk likuidasi karena para anggota tersebut masing-masing akan mendirikan usaha sendiri. 
Persekutuan tersebut didirikan dengan nama Fa" $3 A^{\prime \prime}$ yang mempunyai posisi keuangan sesaat sebelum likuidasi sbb:

\section{NERACA}

Fa" $3 A "$

\begin{tabular}{|c|c|}
\hline $\begin{array}{l}\text { Kas } \\
80.000 .000\end{array}$ & $\begin{array}{l}\text { Hutang Dagang } \\
\text { 100.000.000 }\end{array}$ \\
\hline $\begin{array}{ll}\text { Persediaan } & 220.000 .000\end{array}$ & $\begin{array}{l}\text { Hutang Nn. Afni } \\
50.000 .000\end{array}$ \\
\hline Aktiva Tetap & $\begin{array}{l}\text { Modal Tn. Andi } \\
250.000 .000\end{array}$ \\
\hline $\begin{array}{l}\text { Aktiva Lain-lain } \\
200.000 .000\end{array}$ & $\begin{array}{l}\text { Modal Ny. Ari } \\
300.000 .000\end{array}$ \\
\hline & $\begin{array}{l}\text { Modal Nn. Afni } \\
300.000 .000 \\
\end{array}$ \\
\hline $\begin{array}{ll}\text { Jumlah } & \mathrm{Rp} \\
1.000 .000 .000 & \\
\end{array}$ & $\begin{array}{ll}\text { Jumlah } & \mathrm{Rp} \\
1.000 .000 .000 & \end{array}$ \\
\hline
\end{tabular}

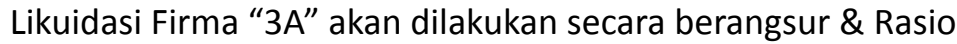
perbandingan Laba Rugi adalah 20\% : 40\% : 40\%. Tahap-tahap realisasi aktiva non kas sbb:

Tahap 1 : Aktiva tetap yang harga pokoknya Rp 300.000.000 laku dijual seharga Rp 240.000.000

Tahap 2 : Persediaan laku dijual dengan harga Rp 250.000.000.

Tahap 3 : Sisa aktiva laku dijual seharga Rp 170.000.000 \& aktiva lain-lain laku dijual seharga Rp 210.000.000.

Diminta : susunlah langkah-langkah pembagian kas dengan program kas sesuai dengan prosedur akuntansinya!

\section{Penyelesaian}

a. Menghitung Kemampuan Untuk Menanggung Rugi Maksimum (KMRM) Masing-Masing Anggota.

\begin{tabular}{|l|l|l|l|}
\hline Keterangan & $\begin{array}{l}\text { Modal Tn. } \\
\text { Andi }(\mathbf{R p})\end{array}$ & $\begin{array}{l}\text { Modal Ny. Ari } \\
(\mathbf{R p})\end{array}$ & $\begin{array}{l}\text { Modal Nn. } \\
\text { Afni (Rp) }\end{array}$ \\
\hline Saldo Modal & 250.000 .000 & 300.000 .000 & 300.000 .000 \\
\hline Piutang Kepada Firma *) & - & - & 50.000 .000 \\
\hline
\end{tabular}




\begin{tabular}{|l|l|l|l|}
\hline Jumlah Investasi & 250.000 .000 & 300.000 .000 & 350.000 .000 \\
\hline Dibagi: Rasio/Laba Rugi & $20 \%$ & $40 \%$ & $40 \%$ \\
\hline $\begin{array}{l}\text { Kemampuan untuk } \\
\text { menanggung rugi } \\
\text { maksimum }\end{array}$ & 1.250 .000 .000 & 750.000 .000 & 875.000 .000 \\
\hline
\end{tabular}

*) Jumlah piutang kepada Firma milik anggota (kreditur intern) disertakan pula sebagai penambahan kekayaan yang tertanam (investasi) dalam Firma.

\section{Menyusun Urutan Prioritas Pembayaran Kas Kepada Anggota}

Berdasarkan pada perhitungan kemampuan menanggung rugi maksimum di atas, maka urutan pembayaran kas dapat disusun sbb:

\begin{tabular}{|c|c|c|}
\hline $\begin{array}{l}\text { Nama } \\
\text { Anggota }\end{array}$ & $\begin{array}{l}\text { Jumlah Kemampuan } \\
\text { Menanggung Rugi } \\
\text { Maksimum }\end{array}$ & $\begin{array}{l}\text { Urutan } \\
\text { Priorita } \\
\text { s }\end{array}$ \\
\hline Tn. Andi & $\begin{array}{ll}\mathrm{Rp} & 1.250 .000 .000 \\
\end{array}$ & 1 \\
\hline Ny. Ari & 750.000 .000 & 3 \\
\hline Nn. Afni & 875.000 .000 & 2 \\
\hline
\end{tabular}

\section{c. Membuat Program Pembayaran Kas}

Berdasarkan kemampuan menanggung rugi maksimum \& urutan prioritas pembayaran dapat dibuat program kas sbb:

\begin{tabular}{|c|c|c|c|c|c|c|}
\hline \multirow[t]{2}{*}{ Keterangan } & \multicolumn{3}{|c|}{ Kapasitas Menanggung Rugi Maksimum } & \multicolumn{3}{|c|}{ Jumlah Prioritas Pembayaran } \\
\hline & Tuan Andi (Rp) & Ny. Ari (Rp) & Nn. Afni (Rp) & Tn. Andi (Rp) & $\begin{array}{l}\text { Ny. Ari } \\
\text { (Rp) }\end{array}$ & $\begin{array}{l}\text { Nn. Afni } \\
\text { (Rp) }\end{array}$ \\
\hline $\begin{array}{l}\text { - Kapasitas } \\
\text { kerugian } \\
\text { maksimum }\end{array}$ & 1.250 .000 .000 & 750.000 .000 & 875.000 .000 & - & - & - \\
\hline \multirow[t]{2}{*}{$\begin{array}{l}\text { - Prioritas ke } \\
1 \mathrm{kpd} \text { Tn. } \\
\text { Andi }\end{array}$} & $(375.000 .000)$ & - & - & 75.000 .000 & - & - \\
\hline & 875.000 .000 & 750.000 .000 & 875.000 .000 & - & - & - \\
\hline $\begin{array}{l}\text { - Prioritas II } \\
\text { kpd Nn. Afni } \\
\text { \& Tn. Andi }\end{array}$ & $(125.000 .000)$ & - & $(125.000 .000)$ & 25.000 .000 & - & 50.000 .000 \\
\hline
\end{tabular}




\begin{tabular}{|c|c|c|c|c|c|c|}
\hline & 750.000 .000 & 750.000 .000 & 750.000 .000 & - & - & - \\
\hline $\begin{array}{l}\text { - Prioritas ke } \\
\text { III kpd semua } \\
\text { anggota }\end{array}$ & $(750.000 .000)$ & $(750.000 .000)$ & $(750.000 .000)$ & 150.000 .000 & 300.000 .000 & 300.000 .000 \\
\hline
\end{tabular}

\section{Daftar Program Pembayaran Kas}

d. Melaksanakan Pembagian Kas dengan Program Kas

Pembagian kas diawali dengan melakukan realisasi aktiva non kas menjadi kas, kemudian barulah diadakan likuidasi.

1. Realisasi tahap 1 dari Firma akan mengakibatkan jumlah kas yang tersedia menjadi Rp 240.000.000 dengan jurnal sbb:

Kas 240.000.000

Modal Tn. Andi 12.000 .000

Modal Ny. Ari 24.000.000

Modal Nn. Afni 24.000 .000

Aktiva Tetap 300.000 .000

Kas yang ada sekarang menjadi Rp 80.000.000 + Rp 240.000.000 $=\mathrm{Rp} 320.000 .000$ yang akan dibayar sesuai dengan tata urutan sbb:

1. Pelunasan hutang dagang \& hutang Nn. Afni, jurnal:

Hutang dagang 100.000.000 Hutang Nn. Afni 50.000 .000 Kas 150.000.000

2. Prioritas pertama kepada Tn. Andi sebesar Rp 75.000.000, jurnal:

Modal Tn. Andi 75.000 .000

Kas 75.000 .000

3. Prioritas kedua kpd Tn. Andi sebesar Rp 25.000.000 \& Nn. Afni Rp 50.000.000 dengan jurnal:

Modal Tn. Andi 25.000.000 Modal Nn. Afni 75.000 .000 
4. Sisa uang yang ada sebesar Rp 320.000.000$(150.000 .000+75.000 .000+75.000 .000)=R p 20.000 .000$, dibagikan kpd para anggota sesuai rasio pembagian laba rugi dengan jurnal:

Modal Tn. Andi

4.000 .000

Modal Ny. Ari

8.000 .000

Modal Nn. Afni

8.000 .000

Kas

20.000 .000

2. Realisasi Tahap II menghasilkan adanya kas sebesar Rp 250.000.000 dengan jurnal realisasi sbb:

Kas

250.000.000

$\begin{array}{lr}\text { Persediaan } & 220.000 .000 \\ \text { Modal Tn. Andi } & 6.000 .000 \\ \text { Modal Ny. Ari } & 12.000 .000 \\ \text { Modal Nn. Afni } & 12.000 .000\end{array}$

Kas yang ada sebesar Rp 250.000.000 akan langsung dibayarkan kepada para anggota sesuai dengan perbandingan laba rugi, langsung dibagikan sesuai dengan Rasio Laba Rugi sebab urutan prioritas pembayaran sudah selesai/ sudah terpenuhi sehingga jurnal likuidasi sbb:

Modal Tn. Andi

Modal Ny. Ari

Modal Nn. Afni

Kas
50.000 .000

100.000 .000

100.000.000

250.000 .000

3. Realisasi Tahap III menghasilkan kas sebesar Rp 380.000.000. Kas yang ada langsung dibagikan kepada para anggota sesuai dengan saldo modal akhirnya dengan jurnal sbb:

Modal Tn. Andi

86.000 .000

Modal Ny. Ari

172.000 .000 
Modal Nn. Afni

Kas
122.000 .000

380.000 .000

BAB 6

Akuntansi Untuk Penjualan Angsuran Aktiva Tetap

\section{Capaian Pembelajaran (CP):}

a. Mahasiswa dapat memahami definisi penjualan angsuran aktiva tetap beserta prosedur akuntansi 
dengan menggunakan metode laba diakui pada tahun penjualan dilakukan dan metode laba diakui proporsionil dengan penerimaan kas

b. Mahasiswa dapat memahami prosedur pencatatan dan perhitungannya apabila terjadi kegagalan dalam pelunasan penjualan angsuran aktiva tetap

\section{A. Penjualan Angsuran Aktiva Tetap}

Penjualan angsuran aktiva tetap adalah penjualan aktiva tetap seperti tanah, bangunan dan sejenisnya yang pembayarannya dilakukan secara bertahap dalam jumlah dan waktu yang telah ditentukan. Biasanya pembayaran angsuran ini mempunyai tata aturan atau persyaratan sebagai berikut :

a. Adanya down payment atau uang muka

b. Pembayaran uang tunai secara periodik sebagai pembayaran angsuran

Pengakuan keuntungan atau laba kotor penjualan angsuran pada penjualan angsuran aktiva tetap dapat dilakukan dengan dua metode yaitu laba kotor diakui pada periode penjualan dan laba kotor diakui secara proporsional sejalan dengan penerimaan kas.

\section{B. Penjualan Angsuran Aktiva Tetap Dengan Menggunakan} Metode Laba Diakui Pada saat Penjualan Angsuran Dilakukan

Berikut contoh kasus untuk mendapatkan gambaran yang lebih jelas tentang metode pengakuan laba kotor dalam penjualan angsuran aktiva tetap.

Contoh 1 : 
Pada tanggal 1 September tahun 2005, PT Graha Property menjual 10 unit rumah dengan harga pokok per kapling Rp $300.000 .000,00$ dan dijual dengan harga Rp 400.000.000,00 ditambah bunga $10 \%$ per tahun. Pembayaran angsuran dilakukan setiap semester ( 6 bulanan) selama 5 tahun atau 10 semester (10 kali angsuran), uang muka 20\% dan bunga dihitung dari sisa pinjaman

Diminta:

- Buat skedul pembayaran angsurannya

- Jurnal transaksi penjualan angsuran dengan asumsi menggunakan metode laba kotor diakui pada saat penjualan dan metode laba kotor diakui sejalan dengan penerimaan kas.

Penyelesaian :

1. Skedul pembayaran angsuran (dalam ribuan $\mathrm{Rp}$ )

\begin{tabular}{|c|c|c|c|c|c|}
\hline Angsuran ke & Tgl bayar & Bunga & Angsuran & $\begin{array}{c}\text { Jml } \\
\text { pembayaran }\end{array}$ & $\begin{array}{c}\text { Sisa harga } \\
\text { kontrak }\end{array}$ \\
\hline & 1 Sept 05 & - & - & - & 4.000 .000 \\
\hline (U.muka) & 1 Sept 05 & - & 800.000 & 800.000 & 3.200 .000 \\
\hline I & 1 Mrt 06 & 160.000 & 320.000 & 480.000 & 2.880 .000 \\
\hline II & 1 Sept 06 & 144.000 & 320.000 & 464.000 & 2.560 .000 \\
\hline III & 1 Mrt 07 & 128.000 & 320.000 & 448.000 & 2.240 .000 \\
\hline IV & 1 Sept 07 & 112.000 & 320.000 & 432.000 & 1.920 .000 \\
\hline V & 1 Mrt 08 & 96.000 & 320.000 & 416.000 & 1.600 .000 \\
\hline VI & 1 Sept 08 & 80.000 & 320.000 & 400.000 & 1.280 .000 \\
\hline VII & 1 Mrt 09 & 64.000 & 320.000 & 384.000 & 960.000 \\
\hline VIII & 1 Sept 09 & 48.000 & 320.000 & 368.000 & 640.000 \\
\hline IX & 1 Mrt 10 & 32.000 & 320.000 & 352.000 & 320.000 \\
\hline X & 1 Sept 10 & 16.000 & 320.000 & 336.000 & 0 \\
\hline \multicolumn{2}{|l|}{ Jumlah Total } & 880.000 & 4.000 .000 & 4.880 .000 & - \\
\hline
\end{tabular}

2. Jurnal transaksi penjualan angsuran dengan menggunakan

a. metode laba kotor diakui saat periode penjualan.

Jurnal yang dibuat sebagai berikut :

(dalam ribuan rupiah) 


\begin{tabular}{|c|c|}
\hline Keterangan transaksi & Jurnal \\
\hline $\begin{array}{ll}\text { la saat penjualan tgl } 1 \text { Sept } 05: \\
10 \times \mathrm{Rp} 400.000=4.000 .000 \\
\text { uang muka } 20 \%=800.000 \\
\text { HP rumah : } \\
10 \times \text { Rp } 300.00=3.000 .000\end{array}$ & $\begin{array}{lr}\text { Kas } & 800.000 \\
\text { Piutang angsuran } & 3.200 .000 \\
\quad \text { Rumah } & \\
3.000 .000 & \\
& \text { Laba penjualan angs } \\
1.000 .000 & \end{array}$ \\
\hline $\begin{array}{l}\operatorname{tgl} 31 \text { Des } 05 \text { : } \\
\text { Bunga yang masih harus diterima } 4 \\
\text { bulan ( } 1 \text { Sept sd } 31 \text { Des } 05) \\
\text { t/12 x } 10 \% \text { x } 3.200 .000=106.667\end{array}$ & $\begin{array}{ll}\text { Piutang bunga } & 106.667 \\
\text { Pendapatan } & \text { bunga } \\
106.667 & \end{array}$ \\
\hline $\begin{array}{l}\text { nal penutup tgl 31 Des } 05 \text { : } \\
\text { Menutup rekening nominal ke } \\
\text { iktisar laba rugi }\end{array}$ & 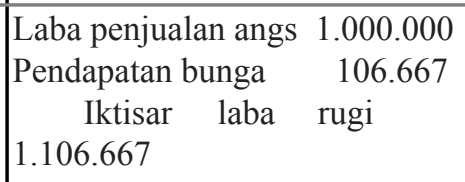 \\
\hline $\begin{array}{l}\text { nal balik tgl } 1 \text { Jan } 06 \text { : } \\
\text { Reversal entries atas bunga yang } \\
\text { akan diterima th. } 2005\end{array}$ & $\begin{array}{l}\text { Pendapatan bunga } \\
\text { Piutang } \\
106.667\end{array}$ \\
\hline $\begin{array}{l}\text { lerimaan angsuran I } \\
\text { Tgl } 1 \text { Maret } 06: \\
\text { Angsuran pokok : } 3.200 .000 / 10 \\
=320.000 \\
\text { Bunga } 6 \text { bln } \times 10 \% / \text { thn } \times 3.200 .000 \\
=160.000\end{array}$ & $\mid \begin{array}{lc}\text { Kas } & 480.000 \\
\text { Piutang } & \text { angsuran } \\
320.000 & \\
\text { Pendapatan } & \text { bunga } \\
160.000 & \end{array}$ \\
\hline $\begin{array}{l}\text { erimaan angsuran II } \\
\quad \text { Tgl } 1 \text { Sept } 06 \\
\text { Angsuran pokok = } 320.000 \\
\text { Bunga } 6 \text { bln x } 10 \% \text { per tahun x } \\
(3.200 .000-320.000)=144.000\end{array}$ & $\begin{array}{lcc}\text { Kas } & & 464.000 \\
& \text { Piutang } & \text { angsuran } \\
320.000 & \\
\text { Pendapatan } & \text { bunga } \\
144.000 & \end{array}$ \\
\hline $\begin{array}{l}\text { tgl } 31 \text { Desember } 06 \text { : } \\
\text { Bunga yang masih harus diterima } 4 \\
\text { bln } \\
4 / 12 \quad \text { x } 10 \% \quad \text { x } \quad(3.200 .000 \\
640.000)=85.333\end{array}$ & 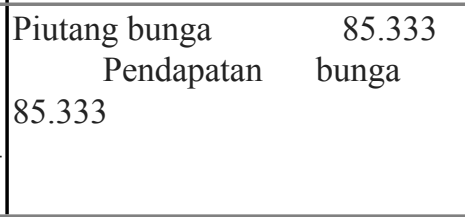 \\
\hline
\end{tabular}

Dari contoh diatas diketahui bahwa dengan menggunakan metode ini pada tahun kedua sudah tidak ada lagi pengakuan laba atas penjualan angsuran rumah. 


\section{Penjualan Angsuran Aktiva Tetap Dengan Menggunakan Metode Laba Diakui Proporsionil Dengan Penerimaan Kas dari Pelunasan Angsuran}

Jurnal yang dibuat adalah sebagai berikut :

(dalam ribuan rupiah)

Keterangan transaksi

Jurnal

\begin{tabular}{|c|c|c|}
\hline Keterangan transaksi & \multicolumn{2}{|c|}{ Jurnal } \\
\hline $\begin{array}{ll}\text { la saat penjualan tgl } 1 \text { Sept } 05: \\
10 \times \mathrm{Rp} 400.000=4.000 .000 \\
\text { uang muka } 20 \%=800.000 \\
\text { HP rumah : } & \\
10 \times \mathrm{Rp} 300.00 & =3.000 .000\end{array}$ & $\begin{array}{l}\text { Kas } \\
\text { Piutang angsuran } \\
\text { Rumah } \\
\text { LKBD }\end{array}$ & $\begin{array}{r}800.000 \\
3.200 .000 \\
3.000 .000 \\
1.000 .000\end{array}$ \\
\hline $\begin{array}{l}31 \text { Des } 05 \text { : } \\
\text { Bunga yang masih harus } \\
\text { diterima } 4 \text { bulan ( } 1 \text { Sept sd } 31 \\
\text { Des 05) } \\
4 / 12 \text { x } 10 \% \text { x } 3.200 .000= \\
106.667 \\
\text { Penyesuaian LKBD atau Laba } \\
\text { kotor direalisasi (LKD) } \\
\text { \% laba kotor: } \\
\frac{1.000 .000}{4.000 .000} 100 \%=25 \% \\
\text { Penerimaan kas th.2005 sebesar } \\
\text { Rp } 800.000 .000(\text { down payment). } \\
\text { Jadi LKD th.2005 adalah } 25 \% \text { X } \\
\text { Rp } 800.000 .000= \\
200.000 .000 \quad \text { Rp }\end{array}$ & $\begin{array}{l}\text { Piutang bunga } \\
\text { Pendapatan bunga } \\
\text { LKBD } \\
\text { LKD }\end{array}$ & $106.667 \quad 106.667$ \\
\hline $\begin{array}{l}\text { Jurnal penutup tgl } 31 \text { Des } 05 \text { : } \\
\text { Menutup rekening nominal ke } \\
\text { iktisar laba rugi }\end{array}$ & $\begin{array}{l}\text { LKD } \\
\text { Pendapatan bunga } \\
\text { Iktisar laba rugi }\end{array}$ & $\begin{array}{l}200.000 \\
106.667 \\
306.667\end{array}$ \\
\hline Jurnal balik tgl 1 Jan 06 & $\begin{array}{c}\text { Pendapatan bunga } \\
\text { Piutang bunga }\end{array}$ & $\begin{array}{r}106.667 \\
106.667\end{array}$ \\
\hline
\end{tabular}




\begin{tabular}{|c|c|c|}
\hline $\begin{array}{l}\text { eversal entries atas bunga yang } \\
\text { akan diterima th. } 2005\end{array}$ & & \\
\hline $\begin{array}{l}\text { Penerimaan angsuran I } \\
\text { [gl } 1 \text { Maret } 06: \text { : } \\
\text { Angsuran pokok : } 3.200 .000 / 10 \\
\begin{array}{rlll} & =320.000 \\
\text { Bunga } 6 \text { bln } & x & 10 \% / \text { thn } \quad x \\
3.200 .000 & & & \\
& & =160.000\end{array}\end{array}$ & $\begin{array}{l}\text { Kas } \\
\text { Piutang angsuran } \\
\text { Pendapatan bunga }\end{array}$ & $\begin{array}{l}320.000 \\
160.000\end{array}$ \\
\hline $\begin{array}{l}\text { rimaan angsuran II } \\
\quad \text { Tgl } 1 \text { Sept } 06 \\
\text { Angsuran pokok = } 320.000 \\
\text { Bunga } 6 \text { bln x } 10 \% \text { per tahun } x \\
(3.200 .000-320.000)=144.000\end{array}$ & $\begin{array}{l}\text { Kas } \\
\quad \text { Piutang angsuran } \\
\text { Pendapatan bunga }\end{array}$ & $\begin{array}{r}464.000 \\
320.000 \\
144.000\end{array}$ \\
\hline 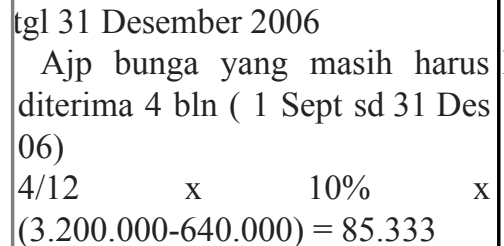 & $\begin{array}{l}\text { Piutang bunga } \\
\text { Pendapatan bunga }\end{array}$ & $\begin{array}{r}85.333 \\
85.333\end{array}$ \\
\hline $\begin{array}{l}\text { Penyesuaian LKBD } \\
\text { Penerimaan kas th.2006 sebesar } \\
\text { Rp } 64.000 .000 \text { (angsuran I dan } \\
\text { II). Jadi LKD th. } 2006 \text { adalah } 25 \% \\
x \quad \text { Rp } 640.000 .000=\text { Rp } \\
160.000 .000\end{array}$ & $\begin{array}{r}\text { LKBD } \\
\text { LKD }\end{array}$ & $\begin{array}{l}160.000 \\
160.000\end{array}$ \\
\hline $\begin{array}{l}\text { Jurnal penutup tgl } 31 \text { Des } 06 \text { : } \\
\text { Menutup rekening nominal ke } \\
\text { iktisar laba rugi }\end{array}$ & $\begin{array}{l}\text { LKD } \\
\text { Pendapatan bunga } \\
\text { Iktisar laba rugi }\end{array}$ & $\begin{array}{l}160.000 \\
85.333 \\
245.333\end{array}$ \\
\hline $\begin{array}{l}\text { Jurnal balik tgl } 1 \text { Jan } 07 \text { : } \\
\text { Reversal entries atas bunga yang } \\
\text { akan diterima th. } 2006\end{array}$ & $\begin{array}{l}\text { Pendapatan bunga } \\
\text { Piutang bunga }\end{array}$ & 85.333 \\
\hline
\end{tabular}

Berikut penjelasan dari jurnal dan perhitungan pada tabel diatas: 
- Laba penjualan angsuran akan diakui setiap tahun yang besarnya tergantung pada besarnya kas yang diterima pada tahun yang bersangkutan. Hal ini dapat dilihat pada tahun 2005 jurnal LKD sebesar Rp 200.000.000, sedangkan untuk tahun 2006 sebesar Rp 160.000.000. Hal ini disebabkan karena jumlah kas yang diterima selama tahun 2005 lebih besar daripada jumlah kas yang diterima pada tahun 2006.

- Jurnal yang dibuat pada tahun 2007 dan berikutnya sama dengan jurnal pada tahun 2006, perbedaannya hanya teletak pada jumlah pendapatan bunga yang semakin kecil karena bunga dihitung dari saldo pokok pinjaman dimana saldo pokok pinjaman akan semakin kecil karena adanya pelunasan ditahun sebelumnya.

\section{Kegagalan Pelunasan Piutang Angsuran Aktiva Tetap}

Apabila terjadi si pembeli tidak mampu untuk melunasi angsurannya, maka ini berarti seluruh laba yang diperhitungkan tidak dapat semuanya direalisasikan. Dengan adanya kegagalan pelunasan ini, biasanya aktiva tetap yang terjual dimiliki kembali oleh si penjual dan aktiva tetap tersebut dinilai sebesar nilai pasar pada saat aktiva tetap tersebut ditarik/dimiliki kembali. Sedangkan jumlah pembayaran angsuran yang telah dibayar oleh pembeli tidak dapat diminta kembali oleh pembeli.

Adanya kegagalan pelunasan angsuran tersebut maka pihak penjual akan mengakui adanya laba atau rugi pemilikan kembali. Besarnya laba atau rugi pemilikan kembali yang diakui tergantung pada metode laba yang digunakan dengan ketentuan sebagai berikut:

Jika pencatatan dilakukan dengan metode laba diakui pada saat penjualan, laba atau rugi dihitung dengan 
cara membandingkan nilai aktiva tetap yang dimiliki kembali dengan jumlah piutang angsuran yang belum dilunasi.

Jika pencatatan dilakukan dengan metode laba diakui proposional dengan penerimaan kas maka laba atau rugi dihitung dengan cara jumlah nilai aktiva tetap yang dimiliki ditambah pengurangan laba kotor yang belum direalisasi dibandingkan dengan jumlah piutang angsuran yang belum dilunasi. 


\section{BAB 7}

\section{Akuntansi Untuk Penjualan Angsuran Barang Dagangan}

\section{Capaian Pembelajaran (CP):}

a. Mahasiswa dapat memahami definisi penjualan angsuran barang dagangan beserta prosedur akuntansinya dan penyajiannya dalam laporan keuangan

b. Mahasiswa dapat memahami prosedur prosedur pencatatan dan perhitungannya apabila terjadi masalah pemilikan kembali barang dagangan karena pembeli tidak mampu lagi melunasinya

c. Mahasiswa dapat memahami prosedur pencatatan dan perhitungan transaksi tukar tambah dalam penjualan angsuran.

\section{A. Pengertian Penjualan Angsuran Barang Dagangan}

Penjualan angsuran barang dagangan proses akuntansinya hampir sama dengan penjualan angsuran aktiva tetap. Perbedaannya terletak pada beberapa hal yaitu pada penjualan angsuran barang dagangan tidak memperhitungkan tingkat bunga angsuran, dan metode yang digunakan untuk pencatatan pengakuan laba hanya dengan metode laba yang diakui proposional dengan penerimaan kas.

Seperti halnya pada penjualan angsuran aktiva tetap, untuk penjualan angsuran barang dagangan mempunyai ketentuan - ketentuan sbb: 


\section{Pembayaran uang muka (Down Payment )}

Pembayaran uang muka ini dilaksanakan secara tunai yang jumlahnya sebesar prosentase tertentu dengan harga jual barang dagangan atau sebesar jumlah rupiah yang telah ditentukan.

2. Pembayaran uang tunai periodik sebagai pembayaran angsuran. Besarnya pembayaran angsuran ini telah ditentukan sebelumnya atau dapat juga ditentukan besar kecilnya tergantung pada lamanya jangka waktu angsuran.

Dalam penjualan angsuran barang dagangan ini, tidak ada pengakuan pendapatan bunga seperti pada penjualan angsuran aktiva tetap. Dalam mencatat transaksi-transaksi penjualan perlu untuk membedakan antara penjualan reguler dengan penjualan angsuran. Hal ini sangat penting untuk dapat memberikan data bagi perhitungan laba kotor yng diakui sebagai hasil penerimaan pembayaran piutang dari penjualan angsuran.

Adapun ketentuan akuntansi untuk penjualan angsuran barang dagangan adalah sebagai berikut :

1. Laba diakui sebesar prosentase laba kotor dikalikan kas yang direalisasi dari penjualan angsuran ( proporsional dengan penerimaan kas ).

2. Piutang, penjualan dan LKBD untuk penjualan angsuran diberi tanda tahun terjadinya agar dapat diidentifikasi dengan jelas hubungannya dengan laba kotor yang realisasi pada tahun yang bersangkutan dengan piutang tersebut.

3. Pencatatan persediaan barang dagangan dapat menggunakan metode pisik atau metode perpetual.

\section{B. Masalah Pemilikan Kembali Barang Dagangan}


Apabila pembeli gagal untuk memenuhi kewajiban yang sudah disepakati dalam surat perjanjian, maka barang-barang yang bersangkutan ditarik dan dimiliki oleh penjual.

Pencatatan yang harus dilakukan dalam buku-buku penjual yaitu :

a. pencatatan pemilikan kembali barang dagangan

b. menghapus saldo piutang penjualan angsuran atas barang-barang tersebut

c. mengakui laba atau rugi pembatalan penjualan angsuran.

Besarnya laba pembatalan penjualan angsuran tergantung pada metode pengakuan laba kotor atas penjualan angsuran yaitu metode accrual dan metode penjualan angsuran

\section{Masalah Tukar Tambah (Trade-In) Dalam Penjualan} Angsuran

Yakni apabila penjual menyerahkan barang-barang baru dengan perjanjian angsuran. Tapi dalam hal ini pembayaran pertama (down payment) dari pembeli berupa barang-barang bekas yang dinilai berdasarkan perjanjian antara kedua pihak.

Barang-barang yang diterima harus dicatat sebesar harga penilaian, yang dianggap sebagai cost (esimated cost). Sedangkan jumlah harga barang yang diterima menurut tawar menawar dalam perjanjian merupakan harga pertukarannya.

Contoh : 
Pada awal tahun 2011 Toko MERDU menjual televisi berwarna secara angsuran seharga RP. 1.375.000. cara p0embayarannya adalah :

1. sebagai uang muka diterima tv bekas yang nilainya disepakati Rp. 375.000

2. sisanya diangsur 10 kali per bulan Rp. 100.000

Tv bekas yang diterima akan diperbaiki dengan biaya Rp. 37.500. setelah diperbaiki harga jualnya seharga Rp. 350.000. perusahaan mengharapkan laba normal $20 \%$ dan biaya pemasaran $5 \%$ dari harga jual. Harga perolehan tv yang baru adalah Rp. 1.000.000

Maka jurnal yang diperlukan adalah :

Harga pertukaran tv bekas

Taksiran biaya perbaikan

Rp. 37.500

Laba normal $=20 \% \times$ Rp. $350.000 \quad$ Rp. 70.000

Biaya pemasaran $=5 \% \times$ Rp. $350.000 \quad \underline{\text { Rp. } .17 .500}$

Taksiran nilai realisasi bersih

Rp. 125.000

Rp. 225.000

Harga yang disepakati

Rp. 375.000

Kelebihan harga

Rp. 150.000

Untuk mencatat penjualan :

Piutang penjualan angsuran $\quad$ Rp. 1.000 .000

Persediaan barang dagangan Rp. 225.000

Cadangan kelebihan harga

Rp. $\quad 150.000$

penjualan angsuran

Rp. 1.375 .000

Untuk mencatat harga pokok penjulalan angsuran :

Harga pokok penjualan angsuran

Rp. 1.000 .000 
untuk mencatat laba kotor penjualan angsuran yang belum direalisasi :

Penjualan anngsuran Rp. 1.375 .000

Harga pokok penjualan angsuran Rp.

1.000 .000

Cadangan kelebihan harga Rp.

150.000

Laba kotor belum direalisasi $\quad$ Rp. 225.000

Besarnya laba kotor terseut dapat dihitung sebagai :

Harga jual yang disepakati

Rp. 1.375 .000

Cadangan kelebihan harga

Rp. $\quad 150.000$

Harga jual yang sesungguhnya Rp. 1.225 .000

Harga pokok penjualan

Rp. 1.000 .000

Laba kotor penjualan angsuran Rp. 225.000 


\section{BAB 8}

\section{Akuntansi Penjualan Konsinyasi Untuk Pengamanat (Consignor)}

\section{Capaian Pembelajaran (CP):}

a. Mahasiswa dapat memahami definisi penjualan konsinyasi dan alasan-alasan bagi pihak pengamanat maupun pihak komisioner mengadakan perjanjian konsinyasi

b. Mahasiswa dapat mengaplikasikan akuntansi penjualan konsinyasi untuk pengamanat

Penjualan Konsinyasi adalah merupakan suatu jenis penjualan dengan cara menitipkan barang dagangan kepada pihak lain untuk dijualkan.

Barang dagangan yang dipakai sebagai obyek penjualan konsinyasi disebut dengan istilah barang konsinyasi. Terdapat perbedaan pokok antara transaksi "penjualan konsinyasi" dengan "penjualan reguler". Perbedaan tersebut adalah:

1. Hak milik barang-barang konsinyasi, hak milik barang tersebut akan berpindah tangan dari pengamanat apabila komisioner sudah berhasil menjual barang tersebut kepada pihak ketiga. Sedangkan untuk penjualan reguler, hak milik 
atas barang akan berpindah kepada pembeli pada saat terjadi transaksi penjualan \& penyerahan barang.

2. Biaya operasi yang berhubungan dengan barang yang dijual. Dalam transaksi penjualan reguler, semua biaya operasi yang berhubungan dengan barang yang dijual ditanggung sendiri oleh si penjual, tetapi dalam penjualan konsinyasi semua biaya yang berhubungan dengan barang konsinyasi akan ditanggung oleh pengamanat. (pemilik barang).

Sebagai alat komunikasi antara pengamanat \& komisioner untuk mengetahui berapa jumlah barang yang telah berhasil dijualkan oleh komisioner beserta jumlah biaya yang telah dikeluarkan oleh komisioner, dibuatlah "LAPORAN PENJUALAN" setiap akhir bulan atau periode tertentu oleh komisioner yang dilaporkan kepada pengamanat.

Dalam pembahasan konsinyasi ini, terdapat bebarapa istilah yang bersangkutan dengan penjualan konsinyasi, yaitu:

a. Pengamanat

b. Komisioner

c. Konsinyasi Keluar

d. Konsinyasi Masuk

Ada beberapa alasan bagi pengamanat untuk mengadakan penjualan konsinyasi :

1. Merupakan salah satu cara yang paling efektif untuk memperluas daerah pemasaran.

2. Barang konsinyasi tidak ikut disita apabila terjadi kebangkrutan pada pihak komisioner sehingga resiko kerugian dapat ditekan.

3. Harga barang yang bersangkutan tetap dikontrol oleh pengamanat. 
4. Jumlah barang yang dijual \& persediaan barang yang ada di gudang mudah dikontrol sehingga resiko kekurangan atau kelebihan barang dapat ditekan \& memudahkan untuk rencana produksi.

Sedangkan alasan bagi komisioner untuk bersedia menerima titipan barang konsinyasi sbb:

1. Komisioner tidak dibebani resiko menanggung rugi bila gagal dalam penjualan barang-barang konsinyasi.

2. Komisioner tidak mengeluarkan biaya operasi penjualan konsinyasi karena semua biaya akan diganti/ditanggung oleh pengamanat.

3. Apabila terdapat barang konsinyasi yang rusak \& terjadi fluktuasi harga, maka hal tersebut bukan tanggungan komisioner.

4. Kebutuhan modal kerja dapat dikurangi, sebab komisioner hanya berfungsi sebagai penerima \& penjual barang konsinyasi untuk pengamanat.

5. Komisioner berhak mendapatkan komisi dari hasil penjualan barang konsinyasi.

Prosedur akuntansi untuk penjualan konsinyasi mempunyai dua metode pencatatan yang dapat digunakan oleh pihak pengamanat maupun oleh pihak komisioner. Dua metode tersebut adalah:

1. Metode Laba Terpisah

2. Metode Laba Tak Terpisah

Barang konsinyasi milik pengamanat yang dititipkan kepada komisioner mempunyai perlakuan akuntansi sbb:

a. Barang konsinyasi yang dikirim kepada komisioner tidak diikuti dengan pemindahan hak milik atas barang yang dikirim tersebut 
sehingga barang konsinyasi tersebut harus tetap dilaporkan sebagai persediaan oleh pengamanat.

b. Pengiriman barang konsinyasi dari pengamanat kepada komisioner bukan merupakan transaksi penjualan sehingga pada saat pengiriman tersebut tidak boleh diakui sebagai adanya pendapatan.

c.Semua biaya yang berhubungan dengan barang konsinyasi tetap menjadi tanggung jawab pengamanat sejak barang tersebut dikirim sampai berhasil barang tersebut dikirim sampai berhasil dijualkan oleh komisioner kepada pihak ketiga.

\section{A. Akuntansi Konsinyasi Pengamanat Dengan Menggunakan Metode Laba Terpisah}

Dalam metode ini transaksi-transaksi konsinyai dipisahkan pencatatannya dari transaksi-transaksi reguler sehingga laba atau pendapatan dari penjualan konsinyasi pencatatannya juga dipisahkan. Untuk mengikuti aliran barang konsinyasi dibuatkan rekening "Konsinyasi Keluar" yaitu Rekening untuk menampung seluruh transaksi yang terjadi pada barang konsinyasi. Pada akhir periode, laba konsinyasi yang dipisahkan pencatatannya tersebut dipindahkan ke rekening laba rugi \& menjadi bagian dari laba usaha keseluruhan.

B. Akuntansi Konsinyasi Untuk Pengamanat Dengan Menggunakan Metode Laba Tak Terpisah

Apabila pengamanat dalam mencatat penjualan konsinyasinya menggunakan metode laba tak terpisah, maka semua transaksi konsinyasi pencatatannya tidak terpisahkan dengan pencatatan transaksi penjualan reguler. Akibatnya dalam metode ini tidak akan timbul rekening baru untuk mencatat transaksi barang konsinyasi tersebut.

Transaksi yang berhubungan dengan barang konsinyasi, akan dicatat seperti transaksi penjualan biasa sehingga pada saat 
konsinyasi tersebut dijual kepada pihak ketiga, perlu diadakan pencatatan harga pokok penjualan oleh pengamanat. Hal ini disebabkan karena seakan-akan barang tersebut hanya berpindah tempat saja. Hanya saja dalam hal ini perlu diadakan memorial (pencatatan tersendiri) agar tidak kehilangan aliran barang konsinyasi tersebut.

Masalah lain yang perlu diketahui dalam penggunaan metode ini adalah bahwa pengamanat tidak menutup rekening pendapatan atau kerugian dari konsinyasi pada akhir periode transaksi konsinyasi. Jadi laba atau rugi karena adanya penjualan konsinyasi tidak dibuatkan jurnal penutup atau tidak ditutup ke rekening laba rugi.

\section{BAB 9}

\section{Akuntansi Penjualan Konsinyasi Untuk Komisioner (Consignee)}

\section{Capaian Pembelajaran (CP):}

a. Mahasiswa dapat memahami prosedur pencatatan akuntansi beserta perhitungannya mengenai transaksi konsinyasi, baik bagi pihak pengamanat maupun pihak komisioner yang masing-masing dengan menggunakan metode Laba Terpisah dan menggunakan metode Laba Tidak Terpisah

b. Mahasiswa dapat mengaplikasikan pencatatan akuntansi beserta perhitungannya mengenai transaksi konsinyasi, baik bagi pihak pengamanat maupun pihak komisioner dengan menggunakan metode Laba Terpisah dan menggunakan metode Laba Tidak Terpisah

Pihak lain yang menerima titipan barang untuk dijualkan tersebut disebut "KOMISIONER" atau CONSIGNEE. Salah satu alasan Komisoner mau menerima barang dari pihak 
pengamanat dengan harapan akan mendapatkan pendapatan komisi apabila berhasil menjualkan barang titipan tersebut.

\section{Adapun kewajiban-kewajiban bagi komisioner akibat adanya} perjanjian konsinyasi dengan pengamanat sbb:

a. Berusaha semaksimal mungkin untuk dapat menjualkan barang konsinyasi tersebut dengan harga \& persyaratan-persyaratan yang ditetapkan dalam perjanjian.

b. Menjaga kemanan \& keselamatan barang-barang konsinyasi dari kecurian, kebakaran, \& resiko fisik lainnya.

c. Mengelola secara fisik maupun akuntansi barng-barang konsinyasi agar mudah diidentifikasi.

d. Membuat laporan penjualan konsinyasi secara periodik kepada pengamanat.

\section{A. Akuntansi Konsinyasi Untuk Komisioner Dengan Menggunakan Metode Laba Terpisah}

Apabila komisioner mencatat transaksi-transaksi barang titipan dengan menggunakan metode laba terpisah dari Laba atas penjualan reguler, maka komisioner akan membuat satu rekening untuk menampung seluruh transaksi barang konsinyasi, yaitu "Konsinyasi Masuk".

Penggunaan rekening "Konsinyasi Masuk" ini adalah sbb:

- Sisi Debit : - Untuk mencatat pengeluaran biaya yang ditanggung oleh Pengamanat

- Untuk Mencatat pengiriman uang ke Pengamanat

- Untuk mencatat pendapatan komisi

- Sisi Kredit : - Untuk mencatat penjualan barang-barang konsinyasi

- Untuk mencatat pendapatan-pendapatan lain yang berhubungan dengan barang konsinyasi

\section{B. Masalah Uang Muka Dalam Penjualan Konsinyasi}


Perjanjian konsinyasi bisa disertai dengan persyaratan adanya uang muka yang harus dibayar Komisioner. Uang muka tersebut berfungsi sebagai jaminan atau dapat juga berfungsi sebagai tanda kesanggupan Komisioner untuk menjualkan barang milik Pengamanat.

Apabila hai ini terjadi, Komisioner pada awal transaksi terlebih dahulu harus membayar sejumlah uang yang besarnya ditentukan dalam perjanjian kepada Komisioner. Jurnal yang harus dibuat oleh Komisionerpada saat menyerahkan uang muka tsb sbb:

Uang Muka Konsinyasi......................XXX

Kas. XXX

Uang muka yang disetorkan kepada Pengamanat tsb, pada akhir periode konsinyasi dapat diminta kembali oleh Komisioner atau langsung dikurangkan pada uang hasil penjualan konsinyasi sebelum disetorkan kepada Pengamanat.

Jumlah uang muka yang diserahkan tsb, tidak boleh dimasukkan dalam rekening konsinyasi masuk sebelah debit, sebab uang muka tersebut merupakan transaksi di luar barang konsinyasi \& bersifat sebagai pengikat atau jaminan.

Dalam laporan keuangan Komisioner, uang muka konsinyasi tersebut disajikan dalam Neraca sebagai Piutang sampai penyelesaian transaksi konsinyasi tersebut berakhir.

\section{Akuntansi Konsinyasi Untuk Komisioner Dengan}

Menggunakan Metode Laba Tak Terpisah

Pada dasarnya, prosedur akuntansi untuk komisioner dengan menggunakan metode laba tak terpisah sama dengan prosedur akuntansi pada metode laba terpisah. Perbedaan yang ada hanya pada rekening yang digunakan untuk mengikuti aliran transaksi konsinyasi. 
Dalam metode laba tak terpisah ini, Komisioner tidak membuat rekening baru. Transaksi dicatat seperti transaksi penjualan biasa.

Untuk mengetahui \& membedakan dengan barangnya sendiri maka setiap transaksi yang berhubungan dengan barang titipan, akan dicatat ke dalam rekening "Nama Pengamanat". Penggunaan rekening ini adalah:

1. Debit $=$

- Untuk mencatat pengeluaran biaya-biaya yang menjadi tanggungan Pengamanat.

- Untuk mencatat Penyetoran uang

2. Kredit $=$

- Untuk mencatat harga pokok penjualan saat terjadinya transaksi penjualan

- Untuk mencatat penerimaan-penerimaan lain \& hasil penjualan konsinyasi. 
BAB 10

Masalah Barang Konsinyasi Yang Belum Terjual Sampai Akhir Periode Akuntansi

\section{Capaian Pembelajaran (CP):}

a. Mahasiswa dapat memahami masalah-masalah yang dapat terjadi pada barang konsinyasi yang belum terjual sampai akhir periode akuntansi

b. Mahasiswa dapat memahami prosedur pencatatan akuntansi beserta perhitungannya apabila terjadi masalah-masalah yang dapat terjadi pada barang konsinyasi yang belum terjual sampai akhir periode akuntansi.

Barang konsinyasi milik si Pengamanat yang dititipkan kepada Komisioner, ada kalanya tidak habis terjual atau dengan kata lain Komisioner belum mampu menjual seluruhnya sampai pada akhir periode akuntansi. Apabila terjadi hal yang demikian, maka 
Pengamanat sebagai pemilik barang konsinyasi tersebut harus mengadakan pencatatan atau penyesuaian, maka laporan keuangan Pengamanattidak mencerminkan keadaan nilai barang dagangan yang sebenarnya. Bagi pihak Komisioner adanya barang konsinyasi yang belum terjual tidak mempengaruhi catatan barng dagangannya, sebab barang konsinyasi tsb memang bukan barang dagangan miliknya, sehingga dalam hal ini Komisioner tidak perlu mengadakan jurnal penyesuaian.

A. Barang Konsinyasi Yang Belum Terjual Pada Akhir Periode Untuk Pengamanat

Apabila terdapat barang konsinyasi yang belum terjual pada akhir periode akuntansi, maka perlu adanya penyesuaian terhadap barang-barang yang dititipkan kepada Komisioner. Secara fisik barang tsb pada akhir periode telah menyerap biaya-biaya untuk pengelolaan barang tsb.

Untuk barang konsinyasi yang belum terjual perlu diadakan penyesuaian dengan cara memperhitungkan biaya-biaya yang telah dikeluarkan baik yang melekat pada barang yang telah dijual maupun yang belum terjual. Penyesuaian terhadap biaya-biaya ini sangat penting dalam penentuan laba rugi periodik.

Apabila telah dapat dipisahkan biaya-biaya yang melekat pada masing-masing barang konsinyasi, maka perlakuan biayanya sbb:

1. Untuk biaya yang melekat pada barang konsinyasi yang telah terjual, maka biaya tersebut diperlakukan sebagai "Biaya Operasi" pada periode berjalan.

2. Untuk biaya yang melekat pada barang konsinyasi yang belum terjual, maka biaya tersebut diperlakukan \& dicatat sebagai "Persekot Biaya" atau "Biaya yang Ditangguhkan pembebanannya." 
B. Barang Konsinyasi Yang Belum Terjual Pada Akhir Periode Untuk Komisioner

Pada pencatatan buku Komisioner, masalah konsinyasi yang belum terjual tidak mengalami penyesuaian atau dengan kata lain tidak ada pengaruh pada pencatatan Komisioner. Hal ini disebabkan karena Komisioner terbatas hanya mencatat barang-barang konsinyasi yang telah berhasil dijualkan \& biaya-biaya yang telah dikeluarkan yang berhubungan dengan penjualan konsinyasi serta pendapatan komisi dari konsinyasi.

Pencatatan \& penjurnalannya sama seperti pada barang konsinyasi yang habis terjual yang telah dibahas sebelumnya, baik dengan menggunakan metode laba terpisah maupun menggunakan metode laba tak terpisah.

\section{BIODATA}

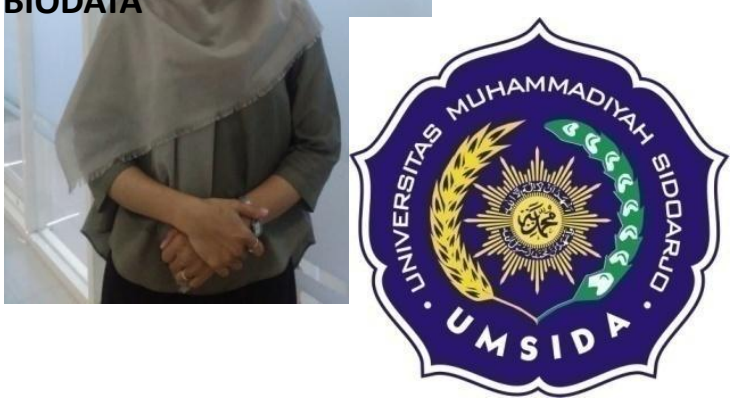

UMSIDA PRESS

SARWENDA BIDURI, SE.,M.SA, lahir di Ambon, 02 April 1985. Menyelesaikan Studi Strata 2 (S2) pada PPS Magister Sains Akuntansi Sekolah Tinggi IImu Ekonomi Indonesia Surabaya (STIESIA) 
tahun 2011. Pengalaman di bidang pendidikan dimulai saat menjadi dosen LB di Fakultas Ekonomi dan Bisnis pada tahun 2010-2011 dan karir sebagai dosen dimulai saat menjadi dosen tetap di Universitas Muhammadiyah Sidoarjo pada tahun 2011 - sekarang. Aktif melakukan penelitian dan penulisan karya ilmiah baik berupa buku ajar, jurnal ilmiah, dan artikel popular. Buku yang telah diterbitkan adalah Modul Kasus Akuntansi Manufaktur (2015). Telah menyelesaikan Buku Aajar Pengantar 1 dan 2 di tahun 2016 dan 2017, mendapatkan Hibah Buku Ajar Tahun 2018 dengan Judul Buku Akuntansi Sektor Publik. 


\section{DAFTAR PUSTAKA}

Arifin, 2002.Pokok-pokok Akuntansi Lanjutan,Edisi Revisi, liberty, Yogyakarta.

Beams, Floyd A., Jusuf, Abadi, Amir, 2000. Akuntansi Keuangan Lanjutan di Indonesia,Salemba Empat, Jakarta.

Evi Maria, 2011, Akuntansi Lanjutan, Penerbit Gava Media, Yogyakarta

F.Zebua, 2009, Akuntasi Keuangan Lanjutan, Penerbit Mitra Wacana Media, Jakarta

Golrida Karyawati. 2012. Akuntansi Keuangan Lanjutan. Erlangga, Jakarta.

Harnanto, Hadori Yunus. 2009. Akuntansi Keuangan Lanjutan. Yogyakarta

Hery. 2014. Prakris Menyusun Laporan Keuangan. PT Grasindo. Jakarta. 
Ikatan Akuntansi Indonesia. 2012. Standar Akuntansi Keuangan. PSAK22. Salemba Empat, Jakarta

Kasmir, 2010. Pengantar Manajemen Keuangan. Cet. 1, Ed. 1, Jakarta : Kencana.

Richard E.Baker, Valdean C. Lembke dan Thomas E.King, 2006, Akuntansi Keuangan Lanjutan, Penerbit Salemba Empat, Jakarta Santoso, Iman. 2009. Akuntansi Keuangan Menengah. Bandung : PT Refika Aditama.

Van Horne James. C, Wachowicz Joh, M., 2007. Prinsio-Prinsip Manajemen Keuangan. Ed. 2, Jakarta : Salemba Empat.

Wibowo, Arif Abubakar, 2009. Akuntansi Keuangan Dasar 2. Jakarta : Cikal Sakti.

Yunus, Hadori dan Harnanto. 2009. Akuntansi Keuangan Lanjutan. Yogyakarta: BPFE

Yunus, Hadori.2013.Akuntansi Keuangan Lanjutan.Yogyakarta:BPFE http://ariefludviakuntansi.blogspot.co.id/2014/11/penggabungan-us ahalaporan-keuangan.html

http://dokumen.tips/documents/tugas-kombinasi-bisnis.html http://sitirohimahfitriah.blogspot.co.id/2015/05/penggabungan-bad an-usaha.html

\section{http://nurul9897.blogspot.com/2018/01/penjualan-angsuran.html}

http://arifkurnia1997.blogspot.com/2016/12/akuntansi-penjualan-a

ngsuran-beserta.html

https://ikhwamuji.wordpress.com/2013/12/27/penjualan-angsuranbarang-bergerakbarang-dagang/

http://windaaviany.web.ugm.ac.id/2015/04/20/akuntansi-penjualanangsuran/ http://ekonomiagungaditya.blogspot.com/2016/12/penjualan-konsi nyasi.html 